\title{
Alteration Mapping for Lead-Zinc-Barium Mineralization in Parts of the Southern Benue Trough, Nigeria, Using ASTER Multispectral Data
}

\author{
Ifeanyi Andrew Oha ${ }^{1}$, Okechukwu Donald Nnebedum ${ }^{1} \&$ Ikenna Anthony Okonkwo ${ }^{1}$ \\ ${ }^{1}$ Department of Geology, University of Nigeria, Nsukka. Nigeria \\ Correspondence: Ifeanyi Andrew Oha, Department of Geology, University of Nigeria, Nsukka. Nigeria
}

Received: February 1, 2021

Accepted: February 26, 2021

Online Published: February 27, 2021

doi:10.5539/esr.v10n1p61

URL: https://doi.org/10.5539/esr.v10n1p61

\begin{abstract}
The lead-zinc-barium deposits of the southern Benue Trough, Nigeria belong to a suite of clastic dominated fracture filling hydrothermal vein deposits. The alteration types and spread are poorly known yet required to aid exploration. Band ratio composites (BRC), Principal Component Analysis (PCA), and Minimum Noise Fraction (MNF) were applied to a full scene Advanced Spaceborne Thermal Emission and Reflection Radiometer (ASTER) imagery covering the study area. Spectral analysis of sulphide minerals known in the area led to the development of the $(\mathrm{B} 1+\mathrm{B} 3) / 2$ ratio, which provided a highly effective sulphide discriminant. PCA and MNF bands with high eigenvectors in the absorption features of target minerals qualified as colour composite candidates for alteration mapping. This study demonstrated the effectiveness of combining the BRC, PCA and MNF techniques in the discrimination of ferric-ferrous/sulphide and silica alteration zones in the Southern Benue Trough.
\end{abstract}

Keywords: ASTER, lead-zinc-barium mineralization, alteration zones, Principal Component Analysis (PCA), Minimum Noise Fraction (MNF)

\section{Introduction}

The Advanced Spaceborne Thermal Emission and Reflection Radiometer (ASTER) consists of a multispectral imaging system made up of 14 bands. Three out of which are in the visible - near-infrared (VNIR), six in the Shortwave Infrared (SWIR) and five within the thermal infrared (TIR) channels. ASTER system having three bands in the VNIR and six bands in the SWIR channels adds to its strength for mapping ferric and sulphide mineral groups since their absorption feature lies within the bands of VNIR-SWIR channels. Deploying ASTER multispectral data in mapping mineral alteration is a well-documented procedure (e.g. Ferrier and Wadge 1996; Ferrier et al. 2002; Heswon et al. 2005; Rowan et al. 2005; Pour and Hashim 2011; Hosseinjani and Tangestani 2011; Tayebi et al. 2013; Cudahy 2012; Elsaid et al. 2014; Testa et al. 2018; Sekandari et al. 2020). Band Ratio on ASTER multispectral data has been utilized to identify alteration associated with ferric iron oxides mineral group like hematite and goethite as well as silicification (Cudahy and Ramanaidou 1996; Rowan and Mars 2003; Rowan et al. 2005; Heswon et al. 2005; Cudahy et al. 2008; Cudahy 2012; Haest et al. 2012). Dickson and Scott (1997) noted that some sulphide-rich, near-surface deposits may form ferruginous capping associated with intense silicification. Principal Component Analysis (PCA) on ASTER bands has been used to delineate alteration zones (Pour and Hashim 2011). Hosseinjani and Tangestani (2011) employed the technique of sub-pixel unmixing of ASTER data in the Sarduiyeh area, Southeast Iran. The contribution of Moghtaderi et al. (2007) recognized the usefulness of the Minimum Noise Fraction (MNF) technique on ASTER multispectral data to map silicic, sodic-calcic and potassic alteration zones.

Lead-Zinc-Barium mineralization has been known in the southern Benue Trough for over a century. However, the first known documentation was in the form of a preliminary report by MacKay (1946), this was followed by a set of generalized but well-documented field-based reports (Farrington 1952; Orajaka 1965). In addition to these early reports, a number of investigations bordering around structural disposition (Ezepue 1984; Maurin and Benkhelil 1990), geophysical characteristics (Etim et al., 1988; Mbah et al., 2015), ore microscopy and fluid inclusion studies (Olade 1976; Olade and Morton 1985; Akande et al. 1988; Akande et al. 1989), Geochemical attributes (Olade and Morton 1985; Akande and Mucke 1993) were reported. The Benue Trough galena-sphalerite-baryte occurrences are formed by open space filling in faults, hence they are generally considered to be epigenetic fracture filling deposits (Ezepue 1984; Oha et al. 2017). Oha et al. (2017) summarized the main characteristics of the lead-zinc-barium mineralization in the Benue Trough as (i) the ores are epigenetic; (ii) they are hosted in a wide variety of lithologies; (iii) they are locally closely spatially associated with Cretaceous igneous intrusions, but post-date them; (iv) mineralization occurs as veins ranging from 5-80 cm wide with 
length up to $2 \mathrm{~km}$ in length; (v) veins are structurally controlled with NW-SE and near N-S trends predominating with subordinate ENE-WSW trends; (vi) ore crystallization temperatures rarely exceed $200^{\circ} \mathrm{C}$; (vii) wall rock alteration is generally minimal; (viii) they are locally associated with saline springs.

The assertion that wall-rock alteration around mineralized veins in the Benue Trough is "minimal" is merely based on fieldwork which were poorly supported by mineral spectra studies. Recent fieldwork has revealed the existence of ferric/ferrous bands, extensive silicification and occasional kaolinization around mineralized veins. This study employed a combination of band ratio composites (BRC), minimum noise fraction (MNF) and principal component analysis (PCA) over a full aster scene covering areas around the Abakaliki-Enyigba-Ameri lead-zinc deposits and the Iyamitet-Obubra-Ekukunela baryte deposits. The goal is to map areas of ferric/ferrous, silica and sulphide alteration and to explore its usability in developing an exploration model for the area.

\section{Geological Setting}

The study area forms part of the Southern Benue Trough in Southeastern Nigeria which has over the years developed into a regional focal point of multifaceted geological research. This is due to its very interesting stratigraphic and structural interplay coupled with the existence of prominent mineralization in the region (Benkhelil 1989; Akande and Muck, 1993; Oha et al. 2017). The Southern Benue Trough is part of an intra-cratonic basin formed by a series of strike slip faults that originate from the deep basement and are related to large-scale transcurrent movements which led to the separation of Gondwanaland (Benkhelil 1982, 1986; Maurin et al 1985). The main structural element in the southern Benue Trough is the Abakaliki Anticlinorium, which is formed by tightly folded Cretaceous sediments intruded by numerous magmatic rocks (Benkhelil 1987, 1989). It is flanked to the west by the elongate synclinorial structure of the Anambra basin and to the south by the Afikpo Syncline extending southwest towards the thick hydrocarbon rich Niger Delta region (fig. 1). The northeastern tip of the Abakaliki anticlinorium terminates in the Ogoja sub-basin and forms a framework of brittle and ductile features which may be related to the localization of fairly large mineralized veins along the northwestern flank (fig. 2).

The sedimentary fill of the basins in the southern Benue Trough was controlled by cycles of transgressions and regressions and local tectonics (fig. 1). Whereas the transgressive phases were characterized by deposition of shales with shoal carbonates developed on submerged structural highs (platforms, horsts), the regressive phases contained extensive deltaic sediments with thin layers of fine clastics (Umeji 2007). Three main stratigraphic cycles are recorded in the southern Benue Trough: the Aptian - Cenomanian age Asu River Group, the Early to Late Turonian age Ezeaku Group and the Coniacian - Santonian age Awgu Group.

The Asu River Group represents the initial clastic fill of the southern Benue Trough (Petters and Ekweozor 1982). It occupies the core of the Abakaliki anticlinorium and consists of about 3,000 $\mathrm{m}$ thick basal arkosic sandstones and middle marine shales - sandstones. The Cenomanian to Lower Turonian Ezeaku Group overlies the Asu River Group and consists of fossiliferous calcareous sandstones, shales and limestones which were estimated to be $2,100 \mathrm{~m}$ thick (Cratchley and Jones 1965). This is marked by occasional alternation of thick sandstone units with marl and represents a major marine sedimentation spanning through the late Cenomanian and continued into the Early Turonian without a break.

The Awgu Formation overlies the Ezeaku Group and consists of light grey shales, calcareous sandstones and limestones. It is considered a time - equivalent of the Awgu Shale (Reyment 1965) and estimated to be over 1,000 m thick (Benkhelil 1986).

Significant tectonic activity and igneous events characterized the Santonian in the Southern Benue Trough, this resulted in intense folding, accompanied by extensive intrusion of syenites and related alkaline and mafic rocks (Benkhelil 1987; Ojoh 1992). The sediments of the southern Benue Trough were eroded and variably overstepped by the Campanian and Maastrichtian beds of the Anambra Basin. Figure 2 shows the distribution of the geological units in the study area. 


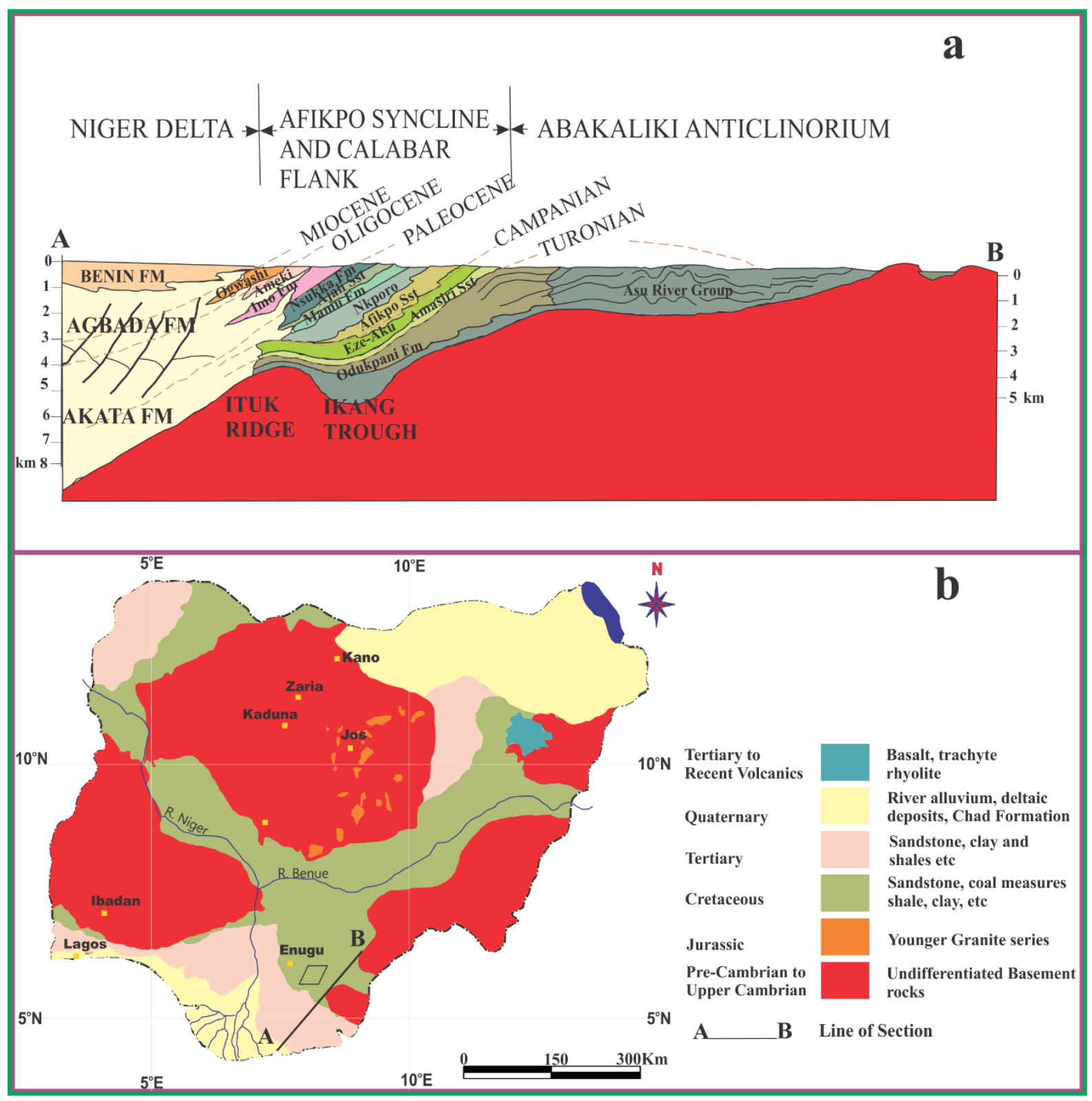

Figure 1. (a) Synthetic crossection along the Niger Delta and Southern Benue Trough, showing the relationships between different lithostratigraphic units. (b) Simplified geological map of Nigeria showing the line of section. (Modified from Ajakaiye 1981; Benkhelil 1989) 


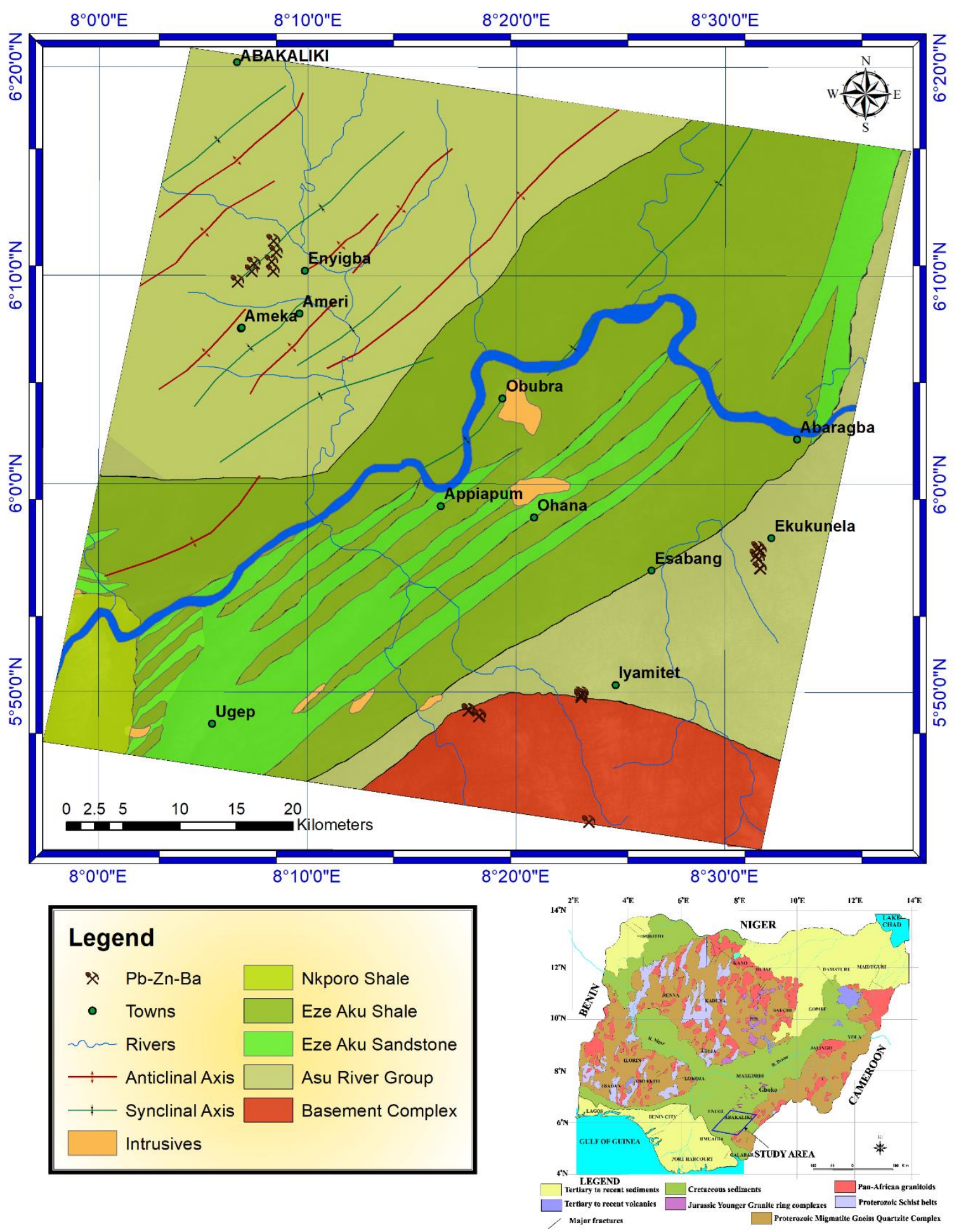

Figure 2. Geological map of the study area. Inset is a generalized geological map of Nigeria, showing the location of the study area 


\section{ASTER Data Analysis}

\subsection{ASTER Data}

The ASTER data used for this work was obtained from the USGS Earth-Data platform accessed via Earth 2 Explorer website. It consists of a one full cloud free level 1T ASTER version 003 imagery covering part of the southern Benue Trough. The scene is a $60 \mathrm{~km}$ by $60 \mathrm{~km}$ multispectral image acquired on February 13, 2007. The ASTER scene used is a level 1T Precision Terrain Corrected Registered At-Sensor Radiance Product with Scene Name AST_L1T_00302132007095618_20150518064053_114484. The data was retrieved in Hierarchical Data 6 Format- Earth Observing System (HDF-EOS). Table 1 shows the characteristics and specification of ASTER multispectral data.

Table 1. ASTER Multispectral Data Specification

\begin{tabular}{|c|c|c|c|c|c|}
\hline \multicolumn{6}{|c|}{ ASTER SPECIFICATION } \\
\hline Instrument Subsystems & Bands & $\begin{array}{l}\text { Wavelength } \\
(\mu \mathrm{m})\end{array}$ & $\begin{array}{l}\text { Spatial } \\
\text { Resolution } \\
(\mathrm{m})\end{array}$ & $\begin{array}{l}\text { Swath width } \\
(\mathrm{Km})\end{array}$ & Signal (bits). \\
\hline $\begin{array}{c}\text { VNIR } \\
\text { Visible and Near Infrared }\end{array}$ & $\begin{array}{l}1 \\
2 \\
3 \mathrm{~N} \\
3 \mathrm{~B}\end{array}$ & $\begin{array}{l}0.520-0.600 \\
0.630-0.690 \\
0.760-0.860 \\
0.760-0.860\end{array}$ & 15 & 60 & 8 \\
\hline $\begin{array}{c}\text { SWIR } \\
\text { Shortwave Infrared }\end{array}$ & $\begin{array}{l}4 \\
5 \\
6 \\
7 \\
8 \\
9\end{array}$ & $\begin{array}{l}1.600-1.700 \\
2.145-2.185 \\
2.185-2.225 \\
2.235-2.285 \\
2.295-2.365 \\
2.360-2.430\end{array}$ & 30 & 60 & 8 \\
\hline $\begin{array}{c}\text { TIR } \\
\text { Thermal Infrared }\end{array}$ & $\begin{array}{l}10 \\
11 \\
12 \\
13 \\
14 \\
\end{array}$ & $\begin{array}{l}8.125-8.475 \\
8.475-8.825 \\
8.925-9.275 \\
10.25-10.95 \\
10.95-11.65 \\
\end{array}$ & 90 & 60 & 12 \\
\hline \multicolumn{6}{|c|}{ ORBIT INFORMATION } \\
\hline Orbit & & rbit Period & Repeat Cycle & Inclination & Altitude \\
\hline $\begin{array}{l}\text { Sun Synchronous } \\
\text { Descending }\end{array}$ & & 8.9 minutes & 16 days & $98.2^{\circ} \pm 0.15^{\circ}$ & $\begin{array}{c}705 \mathrm{Km}(\mathrm{At} \\
\text { equator })\end{array}$ \\
\hline
\end{tabular}

\subsection{ASTER Image Processing}

\subsubsection{Preprocessing}

The AST_L1T data utilizes the appended radiometric and geometric corrections in the raw AST-L1A product. Succeeding this is the terrain and precision corrections carried out by incorporating GLS 2000 digital elevation data with derived ground control points (GCPs) to achieve topographic accuracy. The SWIR and TIR bands were resampled to correspond to the VNIR $15 \mathrm{~m}$ spatial dimension.

\subsubsection{ASTER Spectral Analysis}

According to Dickson and Scott (1997), some sulphide-rich, near-surface deposits may form ferruginous capping associated with intense silicification and the study area is characterized by similar alteration patterns. Sequel to this, ferric oxide mineral group, sulphides, and silica (Quartz) are target minerals for spectral analysis. Fig. 3 contains the different spectral plots of samples of a particular mineral recorded by the same spectrometer (Beckman spectrometer) except for Fig. 3h where Nicolet and AVIRIS spectrometers were used. Fig. 3 (a) - (c) show that the ferric iron mineral group mostly have their absorption feature within the Visible and Near Infrared (VNIR) range. This has also been observed by several authors (Kalinowski and Oliver 2004; Heswon et al. 2005; Cudahy et al. 2008; Pour and Hashim 2011; Cudahy 2012; Abubakar et al. 2018). The sulphide minerals showed some degree of absorption within the VNIR (Fig. 3d \& 3e). Spectra of Galena (Fig. 3f) and Chalcopyrite (Fig. 3g) showed slight absorption within the VNIR. Fig. 3h displays the superimposition of quartz and chalcedony spectral plot having absorption in the Thermal Infrared (TIR) region. These spectra information are required to effectively carry out Band Ratio, PCA and MNF routines. 

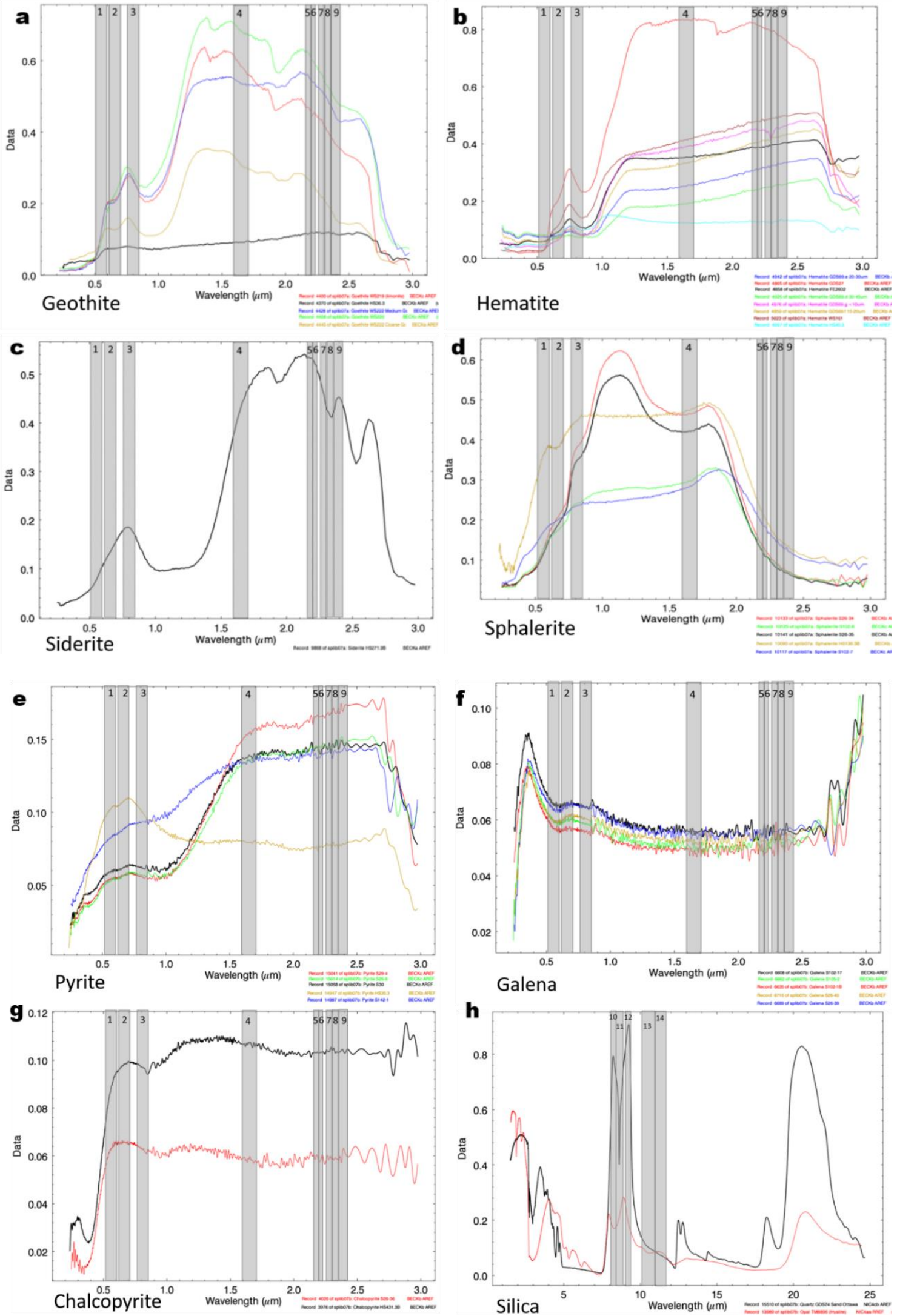

Figure 3. Spectra (USGS library) of selected minerals associated with alteration types in the study area superimposed over ASTER band positions 


\subsubsection{Band Ratios and Combination}

Band Ratio (BR) is performed by dividing the DN value of one or more bands with another with the aim of either enhancing or suppressing certain features. The technique has been employed widely in geological mapping (Kalinowski and Oliver 2004; Rowan et al. 2005; Moghtaderi et al. 2007; Pour and Hashim 2011; Cudahy 2012). In spectral analysis, unique absorption features are usually the desired feature for mineral identification. Certain mineral groups show consistency in absorption at a given bandwidth in the spectral plot (Fig. 3). The ASTER sensors record the reflectance or absorption in the various bands. Bands within the absorption feature for any given mineral group becomes crucial for BR analysis since it contains information for identifying the mineral groups. Careful observation of the spectral plots (for instance, Fig. 3) can give clues of BR or band mathematical expressions that can highlight the absorption feature. Target mineral alteration group for BR analysis as revealed from the geology and nature of alteration in the study area are the ferric, sulphide and silica minerals. Band Ratios utilized are shown in Table 2, whereas the Band Ratio Combinations deployed is given in Table 3. B1- B5, B10, B12, B13 and B14 were designated for ASTER bands 1- 5, 10, 12, 13 and 14, respectively.

Table 2. Band Ratios utilized in the study

\begin{tabular}{|c|c|c|c|c|}
\hline $\mathrm{S} / \mathrm{N}$ & Band Ratio & Feature & Comment & Reference \\
\hline 1 & $\mathrm{~B} 2 / \mathrm{B} 1$ & $\begin{array}{l}\text { Ferric oxide } \\
\text { composition }\end{array}$ & hematite, goethite & $\begin{array}{l}\text { Cudahy and Ramanaidou } \\
\text { 1996; Cudahy, } 2012\end{array}$ \\
\hline 2 & B5/B4 & $\mathrm{Fe}-\mathrm{OH}$ & Siderite & Cudahy (CSIRO), 2012 \\
\hline 3 & $(\mathrm{~B} 1+\mathrm{B} 3) / \mathrm{B} 2$ & Sulphide & Sphalerite \& Pyrite & \\
\hline 4 & $\mathrm{~B} 3 / \mathrm{B} 4$ & Sulphide & Pyrite & \\
\hline 5 & $\mathrm{~B} 1 / \mathrm{B} 4$ & Sulphide & $\begin{array}{l}\text { sulphides in } \\
\text { unoxidized environments }\end{array}$ & Cudahy (CSIRO), 2012 \\
\hline 6 & $\mathrm{~B} 13 / \mathrm{B} 10$ & $\begin{array}{ll}\text { Silica } & (\mathrm{SiO} 2 \\
\text { index }) & \end{array}$ & & $\begin{array}{l}\text { Heswon et. al. 2005; } \\
\text { Cudahy (CSIRO), } 2012\end{array}$ \\
\hline 7 & B14/12 & Silica & & $\begin{array}{l}\text { Rowan \& Mars 2003; } \\
\text { Kalinowski \& Oliver } 2004\end{array}$ \\
\hline 8 & B13/14 & Silica & & \\
\hline 9 & $\mathrm{~B} 13 / 12$ & Silica & & $\begin{array}{l}\text { After Kalinowski \& } \\
\text { Oliver } 2004\end{array}$ \\
\hline
\end{tabular}


Table 3. Ratio and Band Combinations utilized in the study

\begin{tabular}{|c|c|c|c|c|c|}
\hline $\mathrm{S} / \mathrm{N}$ & Features & RED & GREEN & BLUE & Reference \\
\hline 1 & $\begin{array}{l}\text { Fe-OH \& } \\
\text { Sulphide }\end{array}$ & $\mathrm{B} 5 / \mathrm{B} 4$ & $(\mathrm{~B} 1+\mathrm{B} 3) / \mathrm{B} 2$ & MNF1 & \\
\hline 2 & $\begin{array}{l}\text { Ferric \& } \\
\text { Sulphide }\end{array}$ & $\mathrm{B} 2 / \mathrm{B} 1$ & $(\mathrm{~B} 1+\mathrm{B} 3) / \mathrm{B} 2$ & $\mathrm{~B} 3 / \mathrm{B} 4$ & \\
\hline 3 & $\begin{array}{ll}\text { Ferric } \quad \& \\
\text { Silica }\end{array}$ & $\mathrm{B} 2 / \mathrm{B} 1$ & B13/B10 & MNF 1 & $\begin{array}{l}\text { After Rowan and Mars 2003; After } \\
\text { Cudahy (CSIRO) } 2012\end{array}$ \\
\hline 4 & $\begin{array}{l}\text { Fe-OH \& } \\
\text { Silica }\end{array}$ & $\mathrm{B} 5 / \mathrm{B} 4$ & $\mathrm{~B} 13 / \mathrm{B} 10$ & MNF1 & $\begin{array}{l}\text { After Rowan and Mars 2003; After } \\
\text { Cudahy (CSIRO) } 2012\end{array}$ \\
\hline \multirow[t]{2}{*}{5} & \multirow[t]{2}{*}{ Silica } & $\mathrm{B} 13 / \mathrm{B} 10$ & B13/B12 & B13/B14 & \\
\hline & & $\mathrm{B} 13 / \mathrm{B} 10$ & B14/B12 & B13/B14 & $\begin{array}{l}\text { After Rowan and Mars 2003; After } \\
\text { Cudahy (CSIRO) } 2012\end{array}$ \\
\hline \multirow[t]{2}{*}{6} & \multirow{2}{*}{$\begin{array}{l}\text { Ferric, } \\
\text { Silica \& } \\
\text { Sulphide }\end{array}$} & $\mathrm{B} 2 / \mathrm{B} 1$ & B13/B10 & $\mathrm{B} 1 / \mathrm{B} 4$ & After Cudahy (CSIRO) 2012 \\
\hline & & $\mathrm{B} 2 / \mathrm{B} 1$ & B13/B10 & $(\mathrm{B} 1+\mathrm{B} 3) / \mathrm{B} 2$ & \\
\hline \multirow[t]{2}{*}{7} & \multirow{2}{*}{$\begin{array}{l}\text { Ferrous, } \\
\text { Silica \& } \\
\text { Sulphide }\end{array}$} & $\mathrm{B} 5 / \mathrm{B} 4$ & $\mathrm{~B} 13 / \mathrm{B} 10$ & B1/B4 & After Cudahy (CSIRO) 2012 \\
\hline & & $\mathrm{B} 5 / \mathrm{B} 4$ & B13/B10 & $(\mathrm{B} 1+\mathrm{B} 3) / \mathrm{B} 2$ & \\
\hline
\end{tabular}

\subsubsection{Principal Component Analysis}

Principal Component Analysis (PCA), also known as Karhunen - Loeve analysis (Gupta 2018), is used in the analysis of correlated multidimensional data. The PCA process builds a new set of axes orthogonal to each other and ensures non-correlation in the new bands hence reducing its dimensionality. PCA involves the selection of uncorrelated linear combinations of variables in a way that each successive component extracted has linear combination and a smaller variance (Singh and Harrison 1985; Chang et al. 2006; Pour and Hashim 2011). In other words, PCA identifies patterns in data, accentuating its similarities and differences by displaying the most significant variance on the first axis (called Principal Component); the second largest variance, on the second axis that is orthogonal to the first and so on (Gupta et al. 2013). The PC image produced is a display of the sum of the products of eigenvectors and corresponding DN values for spectral bands of the original data at each pixel (Gupta et al. 2013). PCA has been applied effectively for alteration mapping (e.g. Haralick and Fu 1983; Loughlin 1991; Ruiz-Armenta and Prol-Ledesma 1998; Pour and Hashim 2011, Abubakar et al. 2018). The efficacy of the PCA is typified by its ability to (1) identify patterns in data, (2) conserve all the available information in the database and (3) accentuate the similarities and differences in a given database. The eigenvector matrix provides information on how the various input spectral bands contribute to each PCA and hence is valuable in selecting candidate PC bands for PC band combinations. The DN value in the PC image depends upon magnitude and sign of the eigenvectors together with DN values in the input image. Large numeric values of eigenvector loading are considered to have maximum influence irrespective of their sign while low values of eigenvectors would have minimal influence on the resulting PC image (Gupta et al. 2013).

The following considerations were outlined by Gupta et al. (2013), with respect to the combination of large eigenvector with DN values at pixels:

i) Large positive eigenvector combined with high DN value (strong reflection at the pixel) of the input image results in a bright pixel in the PC image.

ii) Large positive eigenvector combined with low DN values (strong absorption) in the input image displays as dark pixels 
in the PC image

iii) Large negative eigenvector combined with high DN value (strong reflection) in the input image results in dark pixels.

iv) Large negative eigenvector combined with low DN value (strong absorption) results in bright pixels in the PC image.

Covariance matrix was used in calculating the principal component. Original ASTER Bands 1- 6 where utilized to calculate Principal Component Transform for the ferric and ferrous alteration zones while Bands $10-14$ were used to calculate for the Silica alteration zone. This is because the absorption feature of ferric and ferrous iron is within the VNIR - SWIR while that of silica is within the TIR region (Fig. 3). Values of the Eigenvectors (Tables 4 and 5) guided the selection of the PC bands used for composites. Relatively large or non-zero eigenvectors (positive or negative) at bands of absorption features of target mineral groups were good choice of PC bands for composites. PC bands 5,3,1 composite segregated the ferric while PC bands 4,2,1 highlighted the ferrous alteration zones. PC bands 10,11,12 and 10,11,14 discriminated the silica rich zones.

\subsubsection{Minimum Noise Fraction (MNF) Method}

Minimum Noise Fraction (MNF) technique and Principal Component Analysis (PCA) are comparable. The MNF technique is used to identify the inherent dimensionality of image data and to successively segregate noise (Green et al. 1988). Eigenvectors of MNF transform, just as in PCA, provides a measure of its information content (Boardman and Green 2000; Pour and Hashim, 2011) where the noisier bands possess near zero values. Limited to no spatial coherence, as well as high degree of dominant incoherent noise are observed in bands with low or near zero eigenvectors. Pour and Hashim (2011) suggested that MNF transform can be used to identify anomalous spectral signature which are indicative of alterations due to hydrothermal mineralization.

Original ASTER Bands 1- 6 were utilized in calculating MNF transform for the ferric and ferrous alteration zones while Bands $10-14$ were used to calculate that of silica. Non-zero (relatively larger) eigenvector loading observed at original bands containing known absorption feature for ferric/ferrous iron as well as silica, guided the choice of MNF bands selected for composites.

For ferric/ferrous alteration mapping using MNF technique, MNF 123 composite was found to moderately discriminate the zones of ferric iron alteration. MNF 126 composite was a better composite for the segregation of high ferrous iron content zones while MNF 10,11,12 as well as MNF 11, 12, 14 gave useful distinction for the high silica content area.

\section{Results and Discussion}

\subsection{Band Ratio Combination}

Band Ratio composites generated were able to discriminate the zones of alteration associated with ferric/ferrous mineral group, sulphide and silica minerals. The result of the various mineral group mapped using this technique are discussed in subsequent subsections.

\subsubsection{Ferric/Ferrous and Sulphide Alteration Mapping}

Band Ratio of B2/B1 is a good discriminant of the ferric oxide content zone (Cudahy 2012; Kalinowski and Oliver 2004). The sulphide element is facilitated by considering the spectral plot of 5 different samples of Sphalerite (see fig. 3d). Three of the samples showed an onset of drop in reflectance (absorption) at Band 3. The spectral plots of the five samples of Sphalerite in Fig 3d experienced some kind of drop in reflectance within the VNIR (Band 1-3). Fig. 3e also has five spectral plots of different samples of Pyrite from the USGS laboratory. Four out of the five plots showed poor absorption in Band 1 and Band 3 and substantial reflectance at Band 2. A similar trend is observed in Fig. 3f (spectral plots of 5 different samples of Galena) and in Fig. $3 \mathrm{~g}$ (spectral plot of 2 different samples of Chalcopyrite). The implication of this is that a ratio of $(\mathrm{B} 1+\mathrm{B} 3) / \mathrm{B} 2$ would enhance alteration related to the sulphide mineral group. Band Ratio composite of $\mathrm{R}$ : B2/B1; G: B1+B3/B2; B: B3/B4 yielded good discrimination of the ferric and sulphide alteration zone (Fig. 4a), displayed in warm orange colours. This pattern is absent in the southeastern part of the area where sulphate mineralization predominates.

Band Ratio of B5/B4 segregated the Ferrous iron content zone (Cudahy 2012). A Band Ratio composite of R: B5/B4; G: B1+B3/B2; B: B3/B4 yielded good discrimination of the ferrous and sulphide alteration zone (Fig. 4b). Deeper orange to reddish shade in Figs. 4a and b display zones with higher concentrations of ferric iron oxide as well as ferrous iron, respectively. The lighter orange shades represent zones with slightly lower ferric/ferrous concentration than sulphides. 

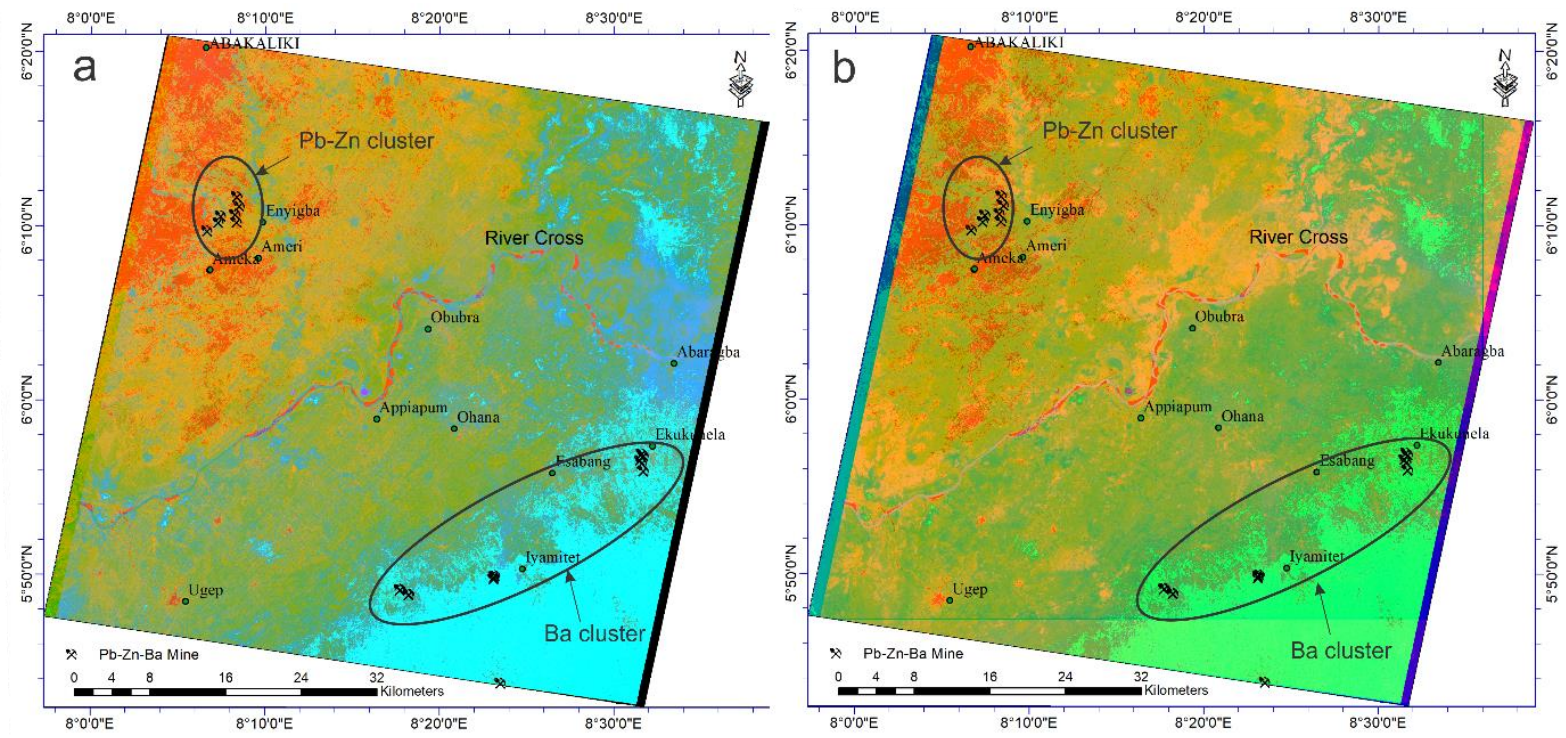

Figure 4. (a) Ferric and sulphide rich band ratio composite R: 2/1, G: $(1+3) / 2, \mathrm{~B}: 3 / 4$ showing zones of ferric and sulphide rich alteration zones in orange - red colouration. (b) Fe-OH and sulphide rich band ratio composite R: 5/4, G: $(1+3) / 2$, B: MNF1 showing zones of $\mathrm{Fe}-\mathrm{OH}$ and sulphide rich alteration in orange - red colouration

\subsubsection{Ferric/Ferrous and Silica Alteration Mapping}

A ratio composite of R: B2/B1; G: B13/B10; B MNF1 discriminated the ferric and silica-rich zones (Fig. 5a). The yellow shades represent the ferric and silica-rich zones. Rowan and Mars (2003) segregated Ferric and Silica-rich zone using a band ratio composite of R: B14/B12; G (B1/B2) + (B5/B3); B: MNF B1. Cudahy (2012) used a ratio of B13/ B10 for delineating silica-rich deposits like quartzites, silicification and silcretes, quartz vein and colluvial/alluvial materials. The ratio used for segregating the ferric and sulphide-rich zone was modified from Rowan and Mars (2003) and Cudahy (2012).

For the ferrous iron and silica-rich zones, BR composite of R: B5/B4; G: B13/B10; B MNF1 gave an acceptable result that correlated with the field validation (see Table 8 and Fig. 13). The reddish shade intervals are areas with a relatively higher concentration of ferric/ferrous iron content.
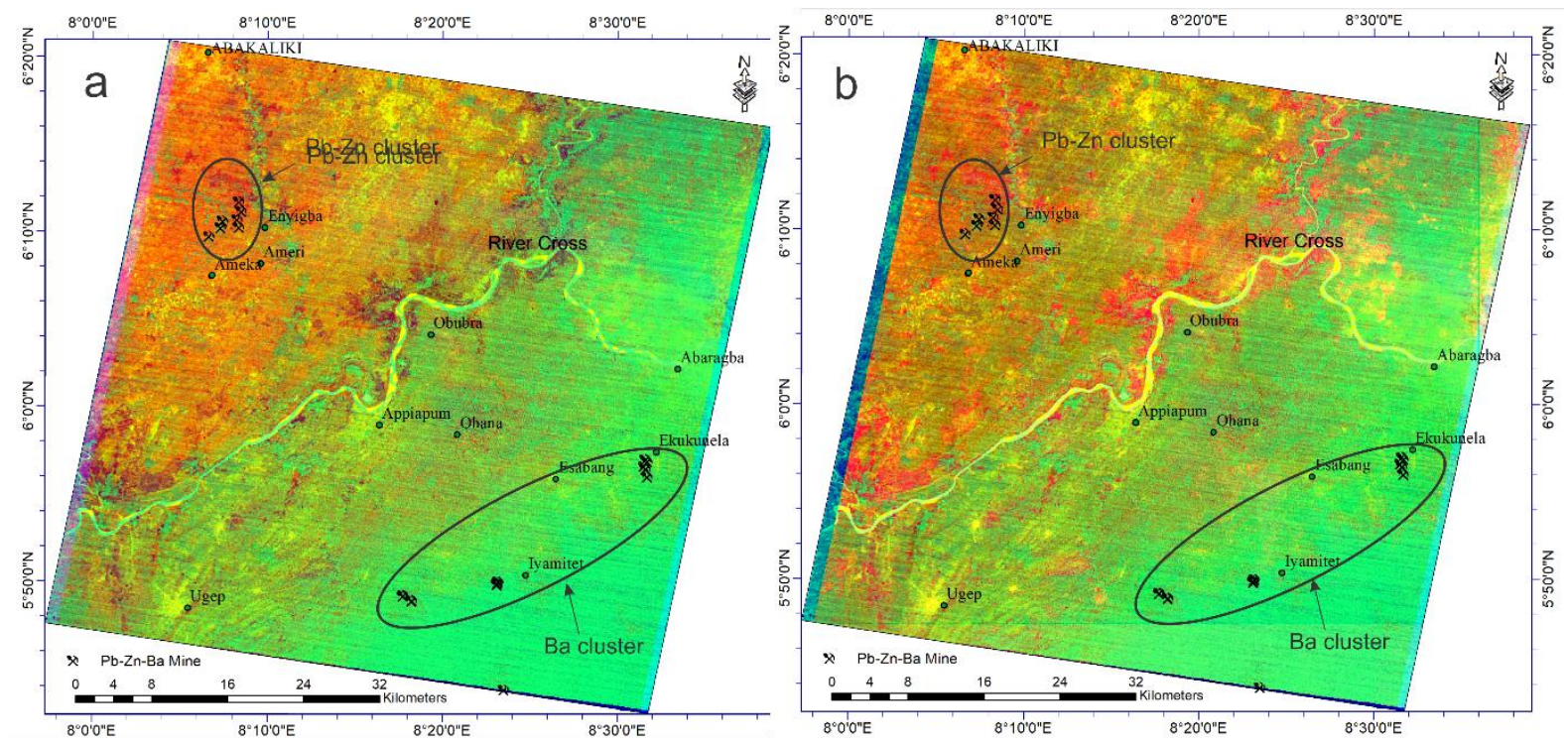

Figure 5. (a) Ferric and silica rich band ratio composite R: 2/1, G: 13/10, B: MNF1, showing zones of ferric and silica rich alteration zones in yellow shades. (b) ferrous and silica rich band ratio composite R: 5/4, G: 13/10, B: MNF1 showing zones of ferrous and silica rich alteration in orange - red colouration 


\subsubsection{Band Ratio Silica Alteration Mapping}

Band Ratio composites of R: 13/10; G: 13/12; B: 13/14 (Fig. 6a) as well as R: 13/10; G: 14/12; B: 13/14 (Fig. 6b) mapped acceptably zones of high silica alteration within the study area. The silica-rich zones appear in warm yellowish colouration in both Figs. 6a and 6b. The alteration pattern is mimicked by the meandering outline of the River Cross, as the silica-rich river beds appear in warm yellow colouration.

Band Ratios B13/10, B14/B12, B13/B12 are established ratios for mapping high silica content (Cudahy 2012 and Kalinowski and Oliver 2004) while B13/B14 is a good ratio for discriminating carbonates (Kalinowski and Oliver 2004). In contrast to the ferric/ferrous/sulphide alteration pattern, the silica-rich alteration pattern manifests a domineering presence around the southeastern part of the study area with stronger presence around the barite rich clusters (see fig 6a and $6 b)$.
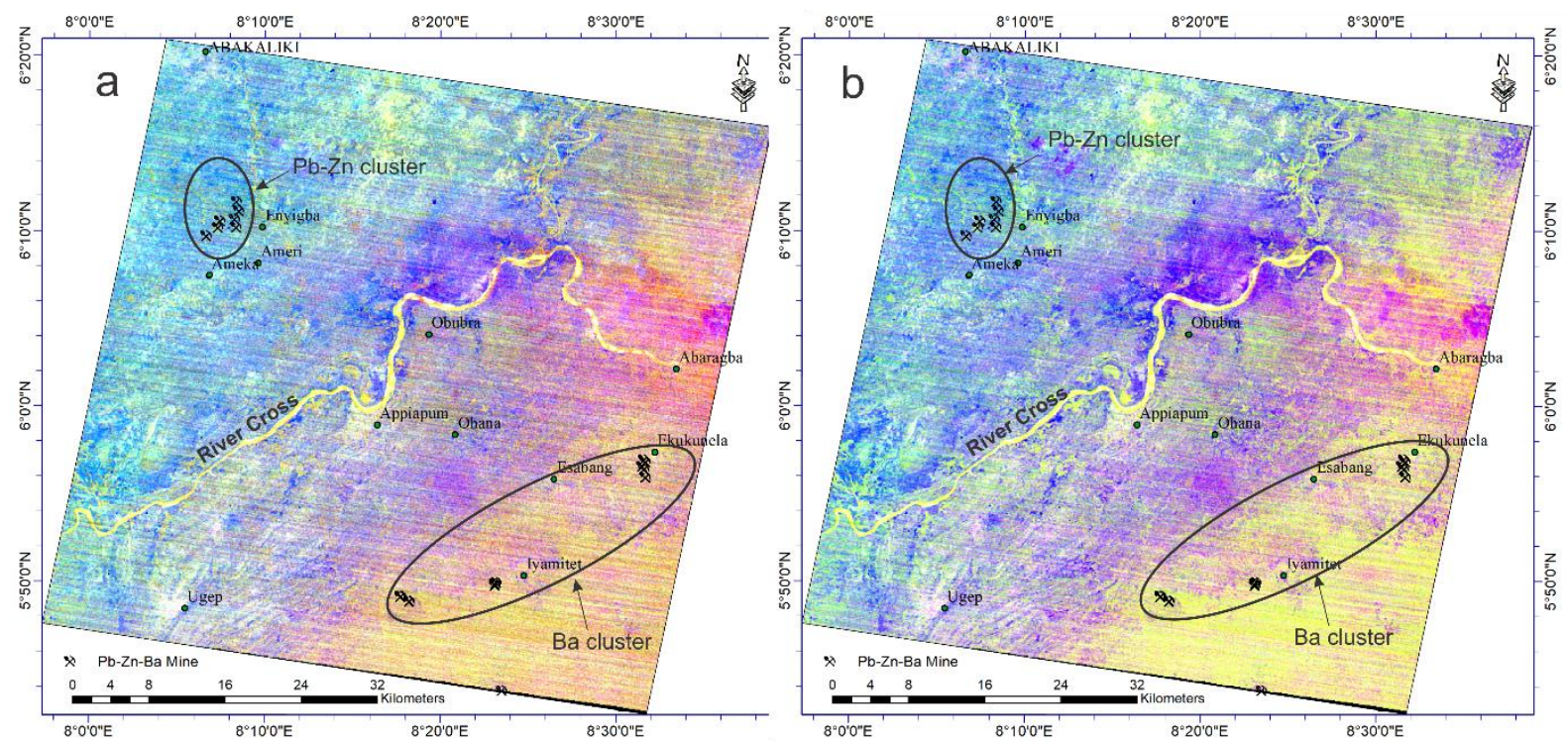

Figure 6. (a) Silica rich band ratio composite R: 13/10, G: 13/12, B: 13/14, showing zones of dominant silica rich alteration zones in yellow shades. (b) Silica rich band ratio composite R: 13/10, G: 14/12, B: 13/14 showing zones of ferrous and silica rich alteration in warm yellow colouration

\subsubsection{Ferric/Ferrous, Silica and Sulphide Alteration Mapping}

An attempt was made to map iron content, silica and the sulphide-rich zones in one composite, and the results are shown in Figs. 7 and 8. Cudahy (2012) showed that the ratio (B1/B4) is useful for mapping sulphide minerals. We compare Cudahy (2012), B1/B4 ratio with $(\mathrm{B} 1+\mathrm{B} 3) / \mathrm{B} 2$ ratio developed in this study and found that the $(\mathrm{B} 1+\mathrm{B} 3) / \mathrm{B} 2$ ratio reveals a more improved sulphide alteration pattern for the study area (fig. 7 and 8 ). Fig. $7 \mathrm{a} \& \mathrm{~b}$ are the composites generated by combinations of R: B5/B4; G: B13/B10; B: B1/B4 and R: B2/B1; G: B13/B10; B B1/B4 respectively, targeted at mapping ferrous/ferric iron, silica and sulphide content using the Cudahy (2012) sulphide band ratio. Also Fig. 8a \& 8b display similar band ratio composite but with the sulphide ratio developed by this research. A significant observation made by these comparisons was that the sulphide ratio employed seemed to have exaggerated the zones with actual observed alterations. The study area, upon field validation, tends to have obvious combinations of either iron and silica alteration or basically iron (lateritic) alterations at sites of obvious mineralization. It is expected that areas with a high content of these three mineral groups in equal proportion should show white shades. However, the recognizable patterns reflect a shift towards the red field of the RGB gun with more of reddish (higher iron content marked by high lateratization) to orange (more of iron than silica marked by some lateratization and few quartz grains exposed at the surface) to yellow (iron and silica almost at similar proportion). However, this observation shows that mapping iron and silica content should be sufficient in delineating the mineralized zones in areas with similar manifestations. 

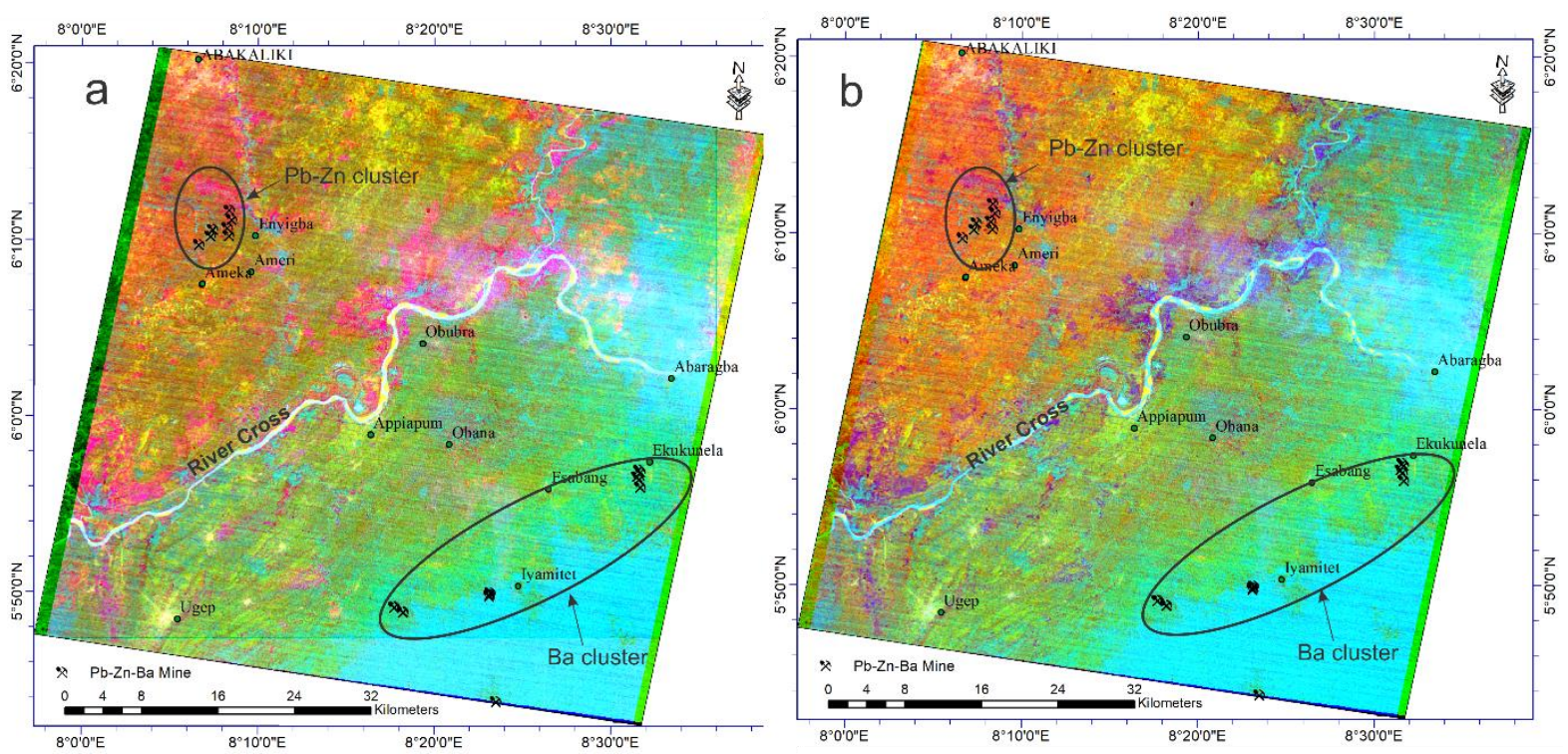

Figure 7. (a) Iron and silica rich band ratio composite R: 5/4, G: 13/10, B: 1/4, showing iron and silica rich zones in one composite which manifest in yellow to orange coloration while magenta to reddish shades are zones of iron and sulphide rich zones. (b) Iron and silica rich band ratio composite R: 2/1, G: 13/10, B: 1/4 also showing iron and silica rich zones in slightly deeper yellow and orange colours than $7 \mathrm{~b}$
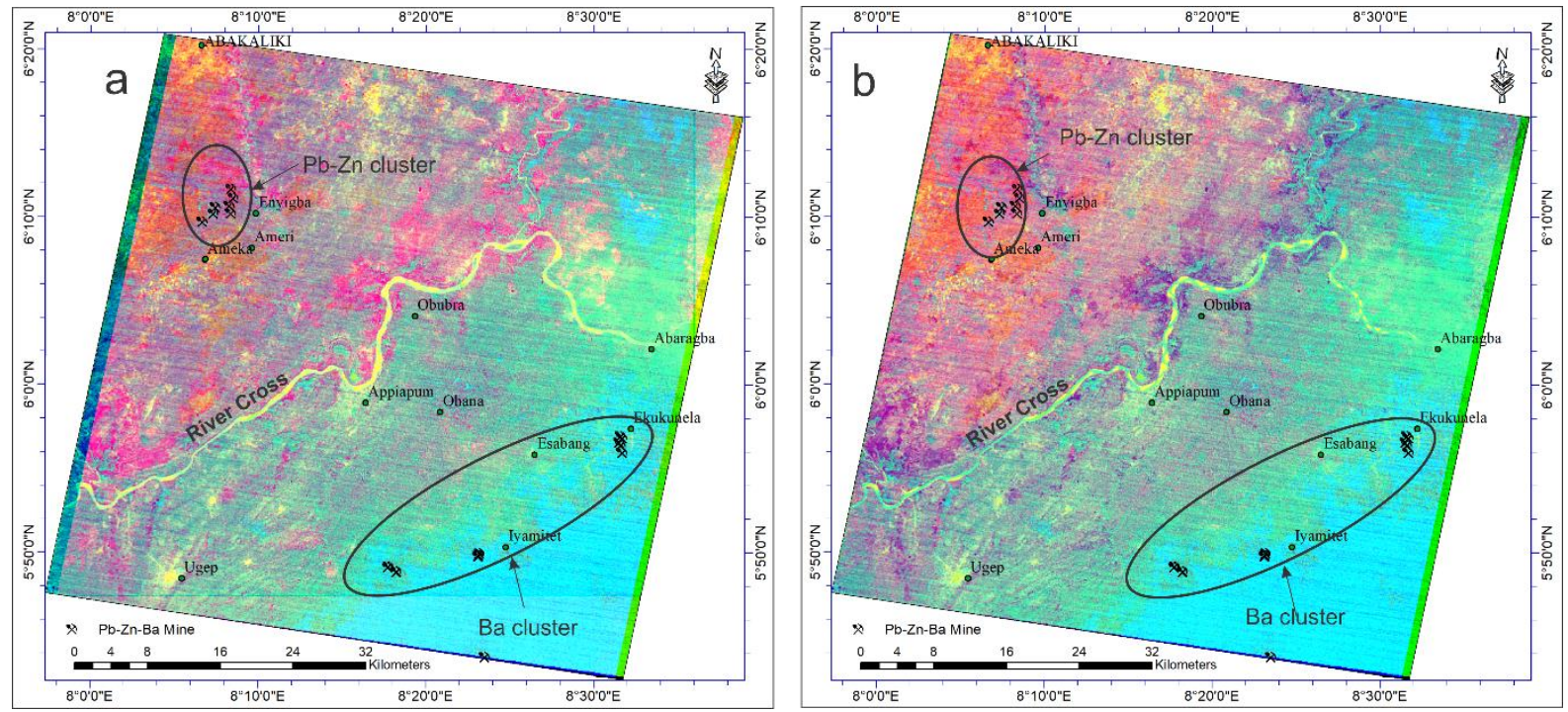

Figure 8. (a) Iron and silica rich band ratio composite R: 5/4, G: 13/10, B: 1+3/2, showing iron and silica rich zones in one composite which manifest in yellow to orange coloration while magenta to reddish shades are zones of iron and sulphide rich zones. (b) Iron and silica rich band ratio composite R: 2/1, G: 13/10, B: 1+3/2 displayed in yellow to orange shades.

The magenta and reddish shades represent zones of iron and sulphide alteration

\subsection{Principal Component Analysis (PCA)}

Results of PCA band combinations were found to precisely discriminate zones of ferric/ferrous, and silica alteration zones which are associated with galena-sphalerite and baryte mineralization in the study area.

\subsubsection{PCA Iron content Alteration Mapping}

The eigenvector loading of the Principal Component Transform calculated from the ASTER bands $1-6$ is shown in Table 4. Relatively higher non-near zero eigenvector loadings are observed at original band 1,2,3 for PC bands 1,3 and 5. A PC composite of 531 gave a good segregation of the ferric mineral group in warm orange colour shade (Fig. 9a). Also, PC composite of 421 gave an acceptable discrimination of the ferrous iron content region in red colour shade (Fig. $9 \mathrm{~b}$ ). This is because relatively higher non-near zero eigenvector loadings are also observed at original band of 4 and 5 for PC bands 1 , 2 and 4. Non zero eigenvectors in original ASTER bands in the region of peculiar absorptions and adjourning reflectance 
of target minerals are usually the best choice for PC composites. In Fig $3 \mathrm{a}-\mathrm{c}$ represents the spectral plots of iron content minerals. Fig 3a (Goethite spectral plots) shows consistent absorption feature in ASTER Bands 1, 2, 3 in four spectral plots out of five from different samples. Highest absorption is observed at Bands 1 followed by bands 2 and 3 . A similar trend is observed in Fig. 3b (Hematite spectral plots) and Fig. 3c (Siderite spectral plot). However, in Fig 3c, a reflectance is observed in Band 3. Also, in the siderite spectral plot, a lower order absorption is noticed at Band 4 whereas a reflectance is seen in Band 5. From these observations, it is obvious to conclude that absorption features at ASTER Bands 1- 3 should be effective in delineating iron content minerals and Bands 4 and 5 can as well be used for the ferrous content discrimination. This explains why PC band with higher non-near zero eigenvector loadings in regions of the above-mentioned ASTER bands were most favourable in segregating the iron rich minerals.
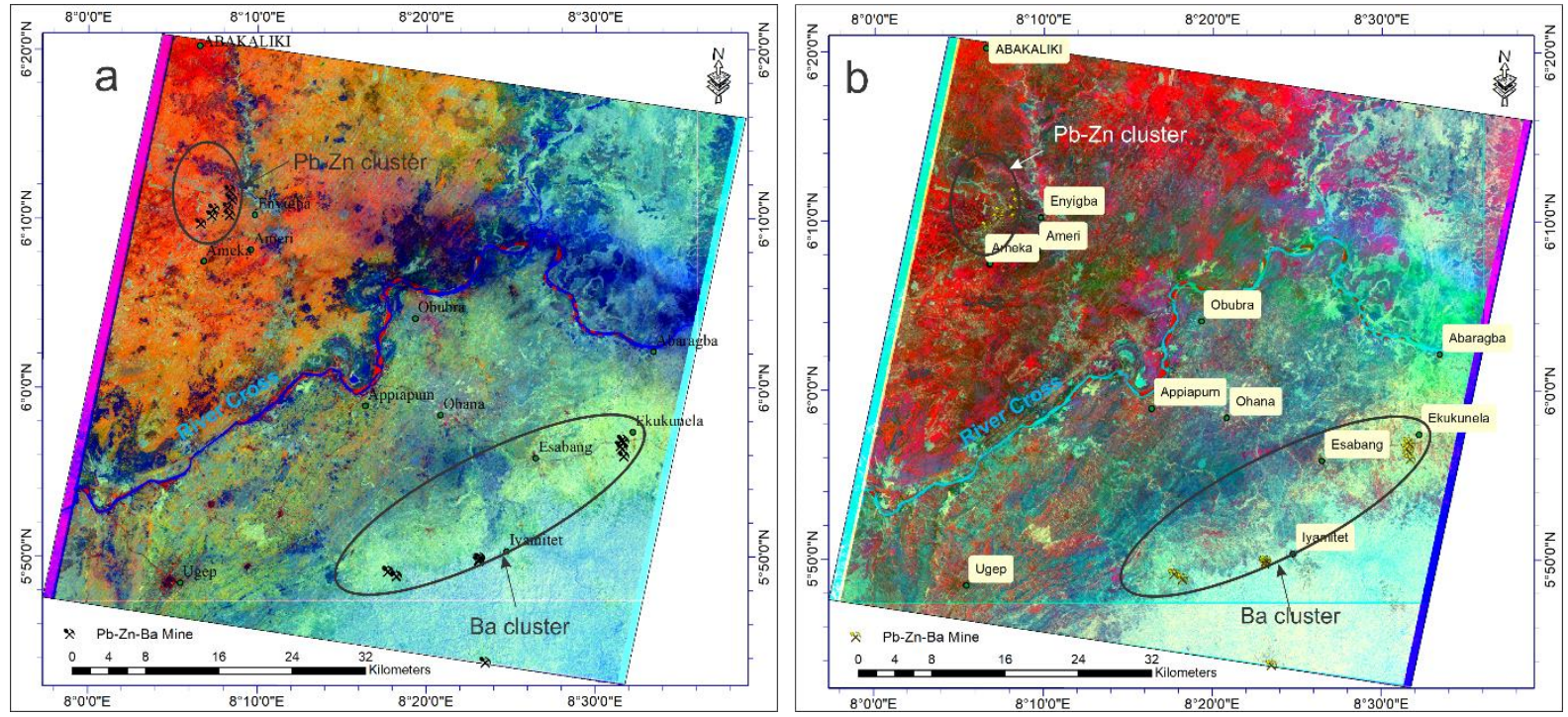

Figure 9. (a) Ferric rich zones deduced from PC colour composites R: PC5, G: PC3, B: PC1 displayed in warm orange to red colours. (b) Ferrous rich zones deduced from R: PC4, G: PC2, B: PC1 displayed in red

Table 4. PCA Eigenvector Statistics for Ferric and Ferrous Alteration Mapping

\begin{tabular}{llllllll}
\hline Eigenvector & Band 1 & Band 2 & Band 3 & Band 4 & Band 5 & Band 6 & $\begin{array}{l}\text { Eigenvalue } \\
(\%)\end{array}$ \\
\hline PC 1 & -0.54859 & -0.43008 & -0.42481 & -0.38625 & -0.2958 & -0.31134 & 95.07107 \\
\hline PC 2 & 0.333242 & 0.008483 & 0.566293 & -0.38566 & -0.4567 & -0.45922 & 3.560585 \\
\hline PC 3 & -0.26319 & -0.60633 & 0.492662 & 0.560022 & 0.015778 & -0.08066 & 0.99972 \\
\hline PC 4 & -0.24164 & -0.16791 & 0.416465 & -0.58531 & 0.248842 & 0.579192 & 0.198928 \\
\hline PC 5 & -0.67807 & 0.647396 & 0.280092 & 0.120357 & -0.10763 & -0.12874 & 0.107406 \\
\hline PC 6 & 0.023654 & 0.002916 & -0.06514 & 0.17713 & -0.79384 & 0.577613 & 0.062337 \\
\hline
\end{tabular}

\subsubsection{PCA Silica Alteration Mapping}

Silica has its absorption in the ASTER TIR range as can be observed in Fig 3h, (Spectral plot of Quartz and Opal). Major pecks of reflectance were observed in Bands 10 and 12 while absorptions were noticed at Bands 11 and 14. Higher non-zero eigenvector loadings in the region of the mentioned bands have proven to be the best for mapping silica in the study area. The eigenvector loading of the Principal Component Transform calculated for the ASTER TIR bands $(10-14)$ is displayed in Table 5. Original bands 11 and 14 happens to be the bands of significant absorption from Fig. 3h. Larger non-zero eigenvectors in Bands 11 and 14 regions are observed at PC bands 10, 11, and 14. PC 12 is also favourable though a near zero eigenvector loading is observed at Band 11. PC bands with relatively higher non-zero eigenvector loadings at original band with absorption features were selected for the PC composites - PC 10,11,12 (Fig. 10a) and PC 10,11,14 (Fig. 10b). A comparison of Fig. 10a and Fig. 10b shows that silica (purple shades) segregation in Fig. 10b seem to be slightly clearer than in Fig. 10a. From the table, it is also observed that larger contrast in eigenvectors of the absorption band with respect to the adjourning reflectance band also contributes to the clarity of the segregation. 


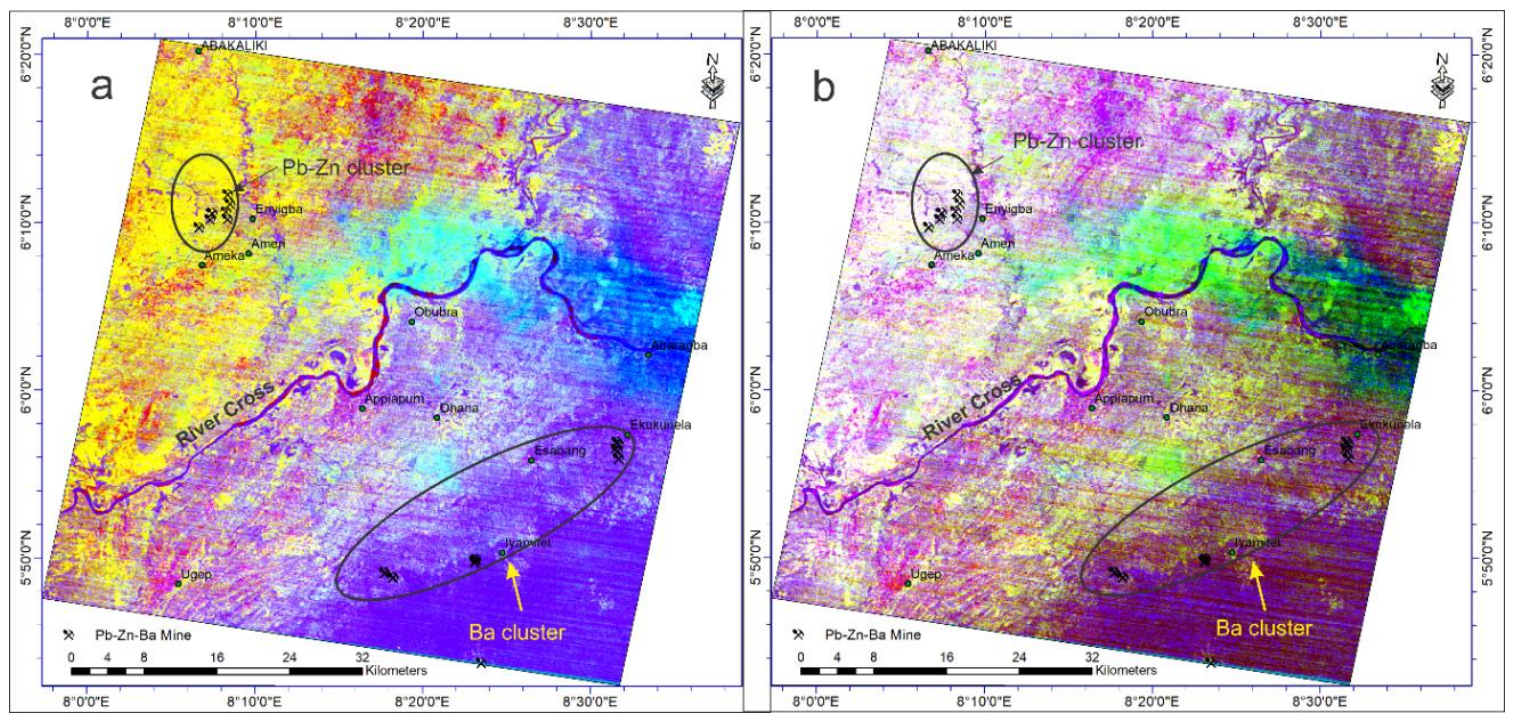

Figure 10. (a) Silica rich zones deduced from PC colour composites R: PC10, G: PC11, B: PC12 displayed in reddish and purple colouration. (b) Silica rich zones deduced from R: PC10, G: PC11, B: PC14 displayed in purple shades

Table 5. PCA_TIR Eigenvector Statistics for Silica Alteration Mapping

\begin{tabular}{llllll}
\hline Eigenvector & Band 10 & Band 11 & Band 12 & Band 13 & Band 14 \\
\hline PC 10 & 0.364946 & 0.397222 & 0.422854 & 0.504195 & 0.525368 \\
\hline PC 11 & 0.139295 & 0.608752 & 0.376839 & -0.22231 & -0.64698 \\
\hline PC 12 & -0.66406 & -0.01184 & 0.596573 & -0.32998 & 0.306753 \\
\hline PC 13 & -0.62094 & 0.232346 & -0.17942 & 0.681134 & -0.25362 \\
\hline PC 14 & -0.14447 & 0.646151 & -0.53954 & -0.35148 & 0.383382 \\
\hline
\end{tabular}

4.3 MNF Analysis

Minimum Noise Fraction transformation using the covariance matrix was able to discriminate the high iron mineral content region (Fig. 11a \& Fig. 11b) as well as silica (Fig. 12).

\subsubsection{MNF Iron Content Alteration Mapping}

The eigenvector loading calculated from ASTER bands 1-6 is provided in Table 6. MNF 1 shows relatively non-zero eigenvector for almost all the original bands except for band 6 (-0.01101). MNF 2 showed near zero eigenvectors in only bands 5 (0.098467) and 6 (0.046817). MNF 3 shows near zero eigenvectors at Band 4 (0.036492) and Band $6(-0.10441)$. in MNF 4, Bands 1 and 4 shows near zero eigenvectors. MNF 5 presents a similar scenario to that of MNF 4 with near zero eigenvectors at Bands 1 and 4. MNF 6 has near zero eigenvectors in original Bands 3, 5 and 6.

Main absorption for the iron minerals (Fig. 3a-c) is observed basically in Band 1 and 2. Band 3 has lower degree of absorption as seen in Fig 3a (goethite spectral plot) and Fig 3b (Hematite spectral plot). For Siderite plot (Fig. 3c), reflectance is noticed at band 3 region. Lower order absorption is also seen at Band 4 with respect to the Band 5 reflectance.

The relatively high non-zero eigenvector at bands of absorption feature in MNF 1,2,3 and 6 explain why MNF composite 123 and 126 acceptably discriminated the ferric and the ferrous iron content zones, respectively. Reddish colour shades depict zone of high iron content (Fig. 11a and Fig. 11b).

Table 6. MNF Eigenvector Statistics for Mapping Ferric and Ferrous alteration Zones

\begin{tabular}{llllllll}
\hline Eigenvector & Band 1 & Band 2 & Band 3 & Band 4 & Band 5 & Band 6 & Eigenvalue \\
\hline MNF 1 & 0.816254 & 0.312953 & -0.35251 & 0.250052 & 0.22109 & -0.01101 & 90.77229 \\
\hline MNF 2 & 0.403205 & -0.67012 & 0.566396 & 0.235958 & 0.098467 & 0.046817 & 5.010741 \\
\hline MNF 3 & -0.25506 & -0.38263 & -0.41301 & 0.036492 & 0.77829 & -0.10441 & 2.696017 \\
\hline MNF 4 & 0.028623 & -0.45986 & -0.56957 & 0.105651 & -0.45784 & 0.492462 & 0.685829 \\
\hline MNF 5 & -0.02565 & 0.237658 & 0.233639 & -0.16049 & 0.35506 & 0.858166 & 0.488014 \\
\hline MNF 6 & -0.32346 & 0.196586 & 0.073214 & 0.918448 & -0.00171 & 0.088423 & 0.347082 \\
\hline
\end{tabular}




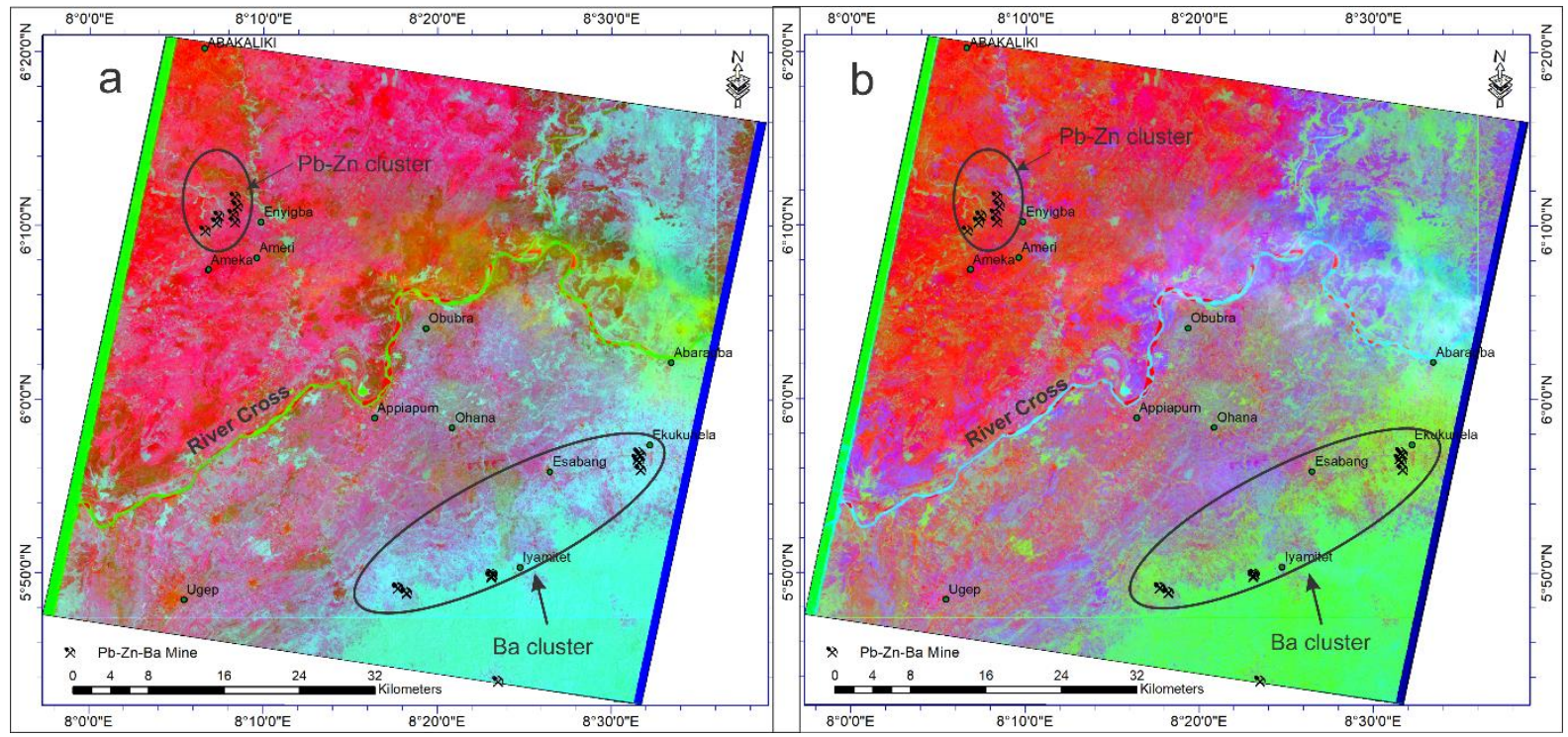

Figure 11. (a) Ferric iron rich zones deduced from MNF colour composites R: MNF1, G: MNF2, B: MNF3 displayed in reddish and purple colouration. (b) Ferrous iron rich zones deduced from MNF colour composites R: MNF1, G: MNF2, B: MNF6 displayed in purple shades

\subsubsection{MNF Silica Alteration Mapping}

MNF transform performed on the ASTER TIR bands gave a good segregation of the silica minerals for selected composites (Fig. 12a). Table 7 shows the MNF eigenvector calculations for the ASTER TIR bands for the study area. MNF 10 gave near zero eigenvector loadings for original Bands 11,12,13 and 14. MNF 11 had a near zero eigenvector loading for only Band 10. MNF 12 also has near zero loading in Band 10, similar to what occurred in MNF 11. More so, near zero eigenvector loading is observed in Band 10 for MNF's 13 and 14.

Following the same approach of generating composites from selected transform bands with relatively higher eigenvector bands especially at the absorption bands for target mineral groups as well as their adjourning reflectance band, MNF 10, 11, 12 (Fig. 12a) as well as MNF 11,12,14 (Fig 12b) gave a good segregation for zones with higher silica abundance. In Fig. 12a, high silica abundance is mapped in yellow - lemon shades while in Fig. 12b it is displayed in purple.

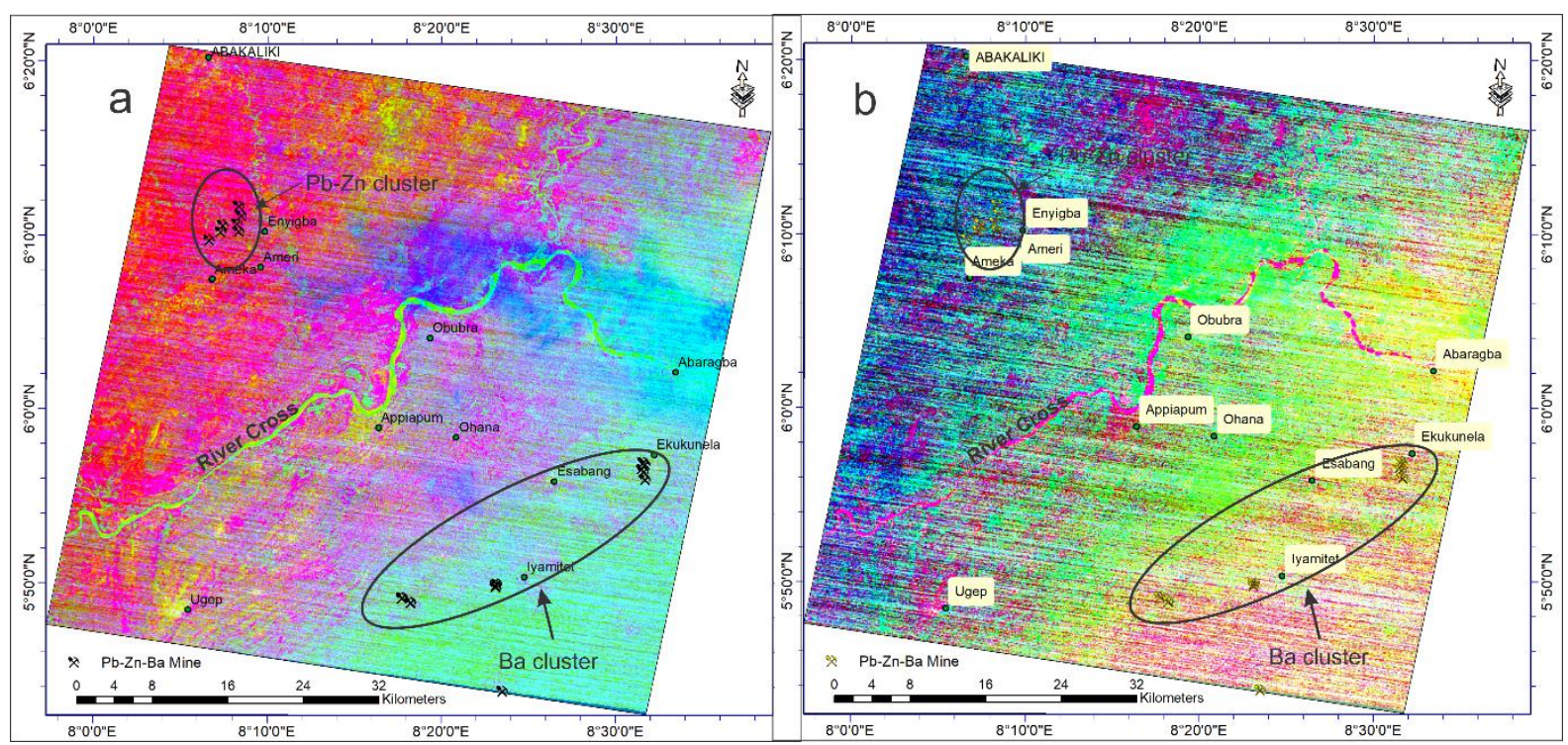

Figure 12. (a) Silica alteration zones deduced from MNF colour composites R: MNF10, G: MNF11, B: MNF12 displayed in yellow and lemon green colouration. (b) Silica alteration zones deduced from MNF colour composites R: MNF11, G: MNF12, B: MNF14 displayed in shades of purple 
Table 7. MNF_TIR Eigenvector Statistics for Mapping Silica alteration Zones

\begin{tabular}{lllllll}
\hline Eigenvector & Band 10 & Band 11 & Band 12 & Band 13 & Band 14 & Eigenvalue \\
\hline MNF 10 & -0.99685 & 0.026685 & -0.0109 & -0.06083 & 0.041914 & 97.90601 \\
\hline MNF 11 & -0.0537 & -0.50297 & -0.58669 & 0.483908 & -0.40715 & 0.678833 \\
\hline MNF 12 & 0.01229 & 0.505045 & -0.2869 & -0.41209 & -0.70189 & 0.511943 \\
\hline MNF 13 & 0.052279 & -0.38265 & -0.49181 & -0.70278 & 0.33922 & 0.455551 \\
\hline MNF 14 & -0.0228 & -0.58721 & 0.575749 & -0.31371 & -0.47409 & 0.447653 \\
\hline
\end{tabular}

\subsection{Data Validation}

Twenty $\mathrm{Pb}-\mathrm{Zn}-\mathrm{Ba}$ mine locations in the study area were visited to validate the alteration data generated. The locations are situated around Enyigba, Ameri and Ameka which forms a cluster of mainly $\mathrm{Pb}-\mathrm{Zn}$ deposits at the northwestern part of the area and around Iyamitet - Ago Ekpo- Ekukunela forming a cluster of mainly baryte deposits at the southeastern part of the area. Ferric/ferrous alteration is observed by the manifestation of bands of hematite, siderite and goethite and predominates around the $\mathrm{Pb}-\mathrm{Zn}$ cluster (figs. 13c and 13d). The presence of quartz rubbles in the host shales are also indications of silica alteration in the area (fig. 13). Silica alteration were reported at the southeastern part of the study area, where they are seen not just as rubbles but consist of thin bands of quartz, significant enough to be considered part of the ore assemblage gangue. Table 8 presents a concise summary of the deposit characteristic in the mine locations visited.

Table 8. Summary of the main characteristics of mine locations visited in the area

\begin{tabular}{|c|c|c|c|c|}
\hline Location & Long & Lat & Mineralization & Description \\
\hline $\begin{array}{l}\text { Ameri-Enyi } \\
\text { gba }\end{array}$ & 8.1106 & 6.1621 & $\mathrm{~Pb}-\mathrm{Zn}-\mathrm{Cu}-\mathrm{Ag}$ & $\begin{array}{l}\text { Extends to } 2 \mathrm{Km} \text { defined by an approximate } \mathrm{N}-\mathrm{S} \\
\text { trend, mined out excavation, shaly lithology with } \\
\text { mainly galena with minor sphalerite, siderite, pyrite } \\
\text { and chalcopyrite. Alteration includes Fe-O, silica } \\
\text { and minor carbonate. }\end{array}$ \\
\hline $\begin{array}{l}\text { Main } \\
\text { Enyigba }\end{array}$ & 8.1391 & 6.1948 & $\mathrm{~Pb}-\mathrm{Zn}-\mathrm{Cu}-\mathrm{Ag}$ & $\begin{array}{l}\text { Dark shaly well fractured lithology exposed along } \\
\text { Ikwo road, with massive mine dumps. Excavations } \\
\text { are in some places up to } 35 \mathrm{~m} \text { deep. }\end{array}$ \\
\hline Enyigba2 & 8.1216 & 6.1704 & $\mathrm{~Pb}-\mathrm{Zn}-\mathrm{Cu}$ & $\begin{array}{l}\text { Host lithology is dark grey fractured shale with } \\
\text { extensive weathering forming Fe-rich enclaves } \\
\text { accompanied with substantial silicification and } \\
\text { associated mangano-siderite. }\end{array}$ \\
\hline $\begin{array}{l}\text { Abandoned } \\
\text { Mine } 1\end{array}$ & 8.139 & 6.1706 & $\mathrm{~Pb}-\mathrm{Zn}$ & $\begin{array}{l}\text { Deep excavation for } \mathrm{Pb}-\mathrm{Zn} \text { in a predominantly dark } \\
\text { shaly terrain. }\end{array}$ \\
\hline $\begin{array}{l}\text { Abandoned } \\
\text { Mine } 2\end{array}$ & 8.1375 & 6.1782 & $\mathrm{~Pb}-\mathrm{Zn}$ & Excavation forms a near oval pond. \\
\hline Enyigba3 & 8.1414 & 6.1858 & $\mathrm{~Pb}-\mathrm{Zn}-\mathrm{Cu}$ & Long Shaly excavation \\
\hline Enyigba4 & 8.1237 & 6.1766 & $\mathrm{~Pb}-\mathrm{Zn}-\mathrm{Cu}$ & $\begin{array}{l}\text { Deep excavation for } \mathrm{Pb}-\mathrm{Zn} \text { in a predominantly dark } \\
\text { shaly terrain. }\end{array}$ \\
\hline Ago Ekpo 1 & 8.2959 & 5.8196 & Baryte & An abandoned baryte mine vein in a thick forest \\
\hline Ago Ekpo 2 & 8.2953 & 5.8192 & Baryte & $\begin{array}{l}\text { Extension of Ago Ekpo } 1 \text { exposed along the river } \\
\text { Ruwein hosted by coarse grained Sandstone. }\end{array}$ \\
\hline Ago Ekpo 3 & 8.3037 & 5.8145 & Baryte & $\begin{array}{l}\text { An abandoned mine pit of baryte, vein hosted by } \\
\text { granitic igneous rock }\end{array}$ \\
\hline Ago Ekpo 4 & 8.3042 & 5.8150 & Baryte & $\begin{array}{l}\text { An abandoned baryte pit hosted by coarse grained } \\
\text { sandstone. }\end{array}$ \\
\hline Iyamitet 1 & 8.3916 & 5.7299 & $\mathrm{Ba}-\mathrm{Pb}-\mathrm{Zn}-\mathrm{Cu}$ & $\begin{array}{l}\text { Exposure of highly weathered vein on the road at } \\
\text { the entrance of New Ekuri village }\end{array}$ \\
\hline Iyamitet 2 & 8.3852 & 5.8299 & Baryte vein & $\begin{array}{l}\text { An active baryte mining pit, associated with galena } \\
\text { and chalcopyrite }\end{array}$ \\
\hline Iyamitet 3 & 8.3853 & 5.8313 & Baryte vein & $\begin{array}{l}\text { Active mine pit, probably an extension of Iyamitet } \\
2 \text {. }\end{array}$ \\
\hline Iyamitet 4 & 8.3862 & 5.8329 & $\mathrm{Ba}-\mathrm{Cu}$ & $\begin{array}{l}\text { Thin exposure of } \mathrm{Ba}-\mathrm{Cu} \text { vein, exposed along the } \\
\text { road. }\end{array}$ \\
\hline
\end{tabular}




\begin{tabular}{|c|c|c|c|c|}
\hline Ekukunela 1 & $\begin{array}{l}8.5249 \\
3\end{array}$ & $\begin{array}{l}5.9432 \\
2\end{array}$ & Baryte & $\begin{array}{l}\text { The baryte pit has a width of } 15 \mathrm{~m} \text { and length of } \\
\text { approximately } 500 \mathrm{~m} \text {, hosted by feldspathic } \\
\text { sandstone with dominant NW/SE trend. }\end{array}$ \\
\hline Ekukunela 2 & $\begin{array}{l}8.5263 \\
8889\end{array}$ & $\begin{array}{l}5.9405 \\
5556\end{array}$ & Baryte & $\begin{array}{l}\text { Baryte vein hosted by sandstone and trending } \\
\text { NW/SE with a width of } 20 \mathrm{~m} \text { and an approximated } \\
\text { length of over } 100 \mathrm{~m} \text {. }\end{array}$ \\
\hline Ekukunela 3 & $\begin{array}{l}8.5264 \\
3 \\
\end{array}$ & $\begin{array}{l}5.9494 \\
1\end{array}$ & Baryte & $\begin{array}{l}\text { Baryte vein hosted by fine grain sandstone, the vein } \\
\text { trends NW-SE with width of about } 5 \mathrm{~m} \text { and extends } \\
\text { for over } 300 \mathrm{~m} \text {. }\end{array}$ \\
\hline Ekukunela 4 & $\begin{array}{l}8.5279 \\
3 \\
\end{array}$ & $\begin{array}{l}5.9331 \\
8 \\
\end{array}$ & Baryte & $\begin{array}{l}\text { Baryte vein hosted by sandstone and trending } \\
\text { NW/SE with a width of } 20 \mathrm{~m} \text { and an approximated } \\
\text { length of over } 200 \mathrm{~m} \text {. }\end{array}$ \\
\hline Ekukunela 5 & $\begin{array}{l}8.5280 \\
5556\end{array}$ & $\begin{array}{l}5.9330 \\
5556\end{array}$ & Baryte & $\begin{array}{l}\text { Fine to medium grain sandstone, lowlying, whitish } \\
\text { in colour has a baryte vein with a width of } 3 \mathrm{~m} \text { and } \\
\text { length of approximately } 15 \mathrm{~m} \text { and a trend of } 145\end{array}$ \\
\hline
\end{tabular}
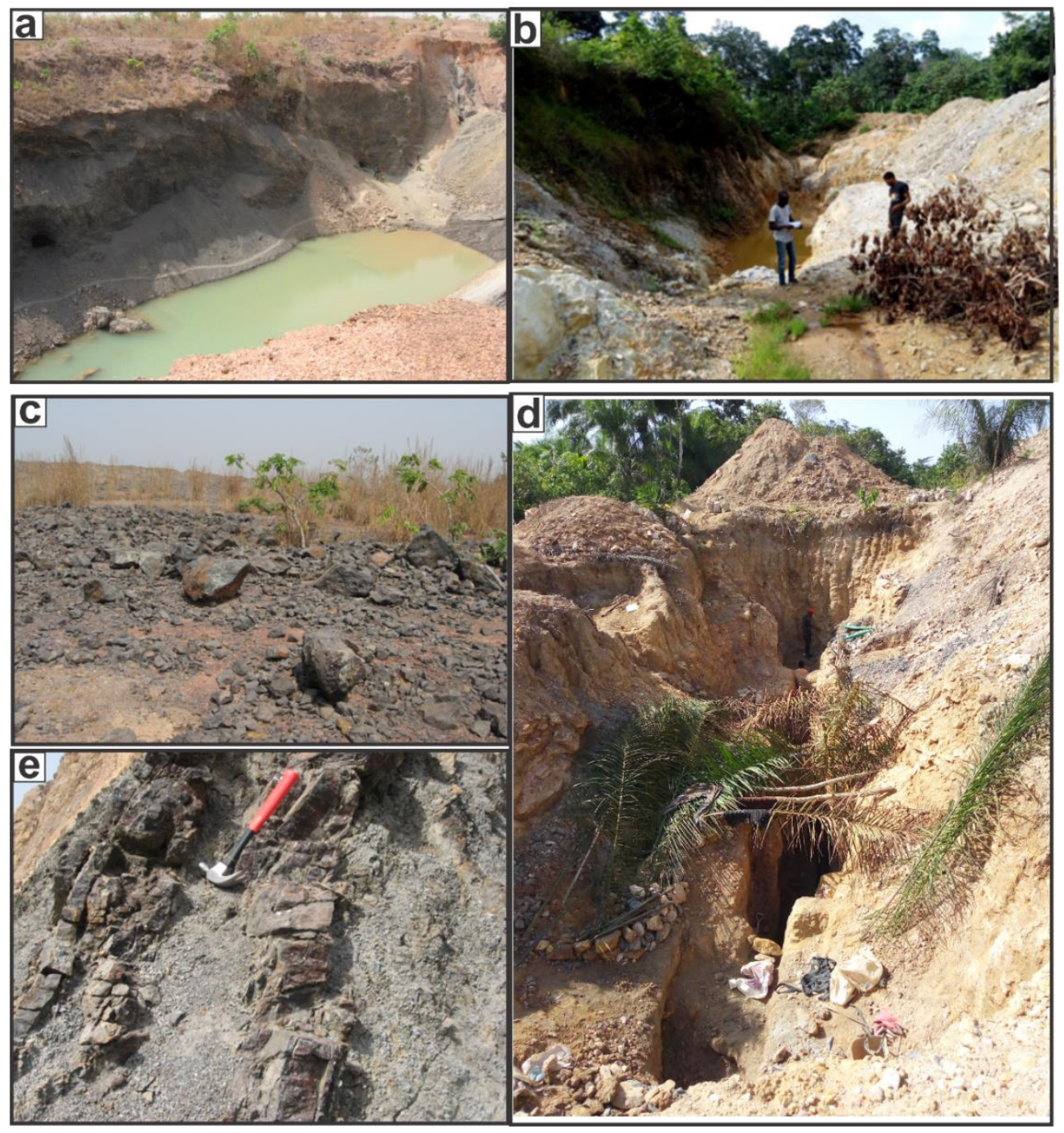

Figure 13. (a) Abandoned $\mathrm{Pb}-\mathrm{Zn}$ mine pit at Enyigba, the wall rock show evidence of silica alteration. (b) Abandoned $\mathrm{Ba}-\mathrm{Pb}-\mathrm{Cu}$ mine at Iyamitet showing traces of silica and ferrous alteration. (c) Extensive ferruginization of argillaceous host rock around Ameri. (d) Active baryte mine pit at Ekukunela showing traces of ferric alteration. (e) ferric bands in the vicinity of $\mathrm{Pb}-\mathrm{Zn}$ mines at Enyigba 


\section{Conclusion}

This study demonstrates the effectiveness of employing BRC, PCA and MNF image transformation techniques in mapping ferric-ferrous/sulphide/silica alteration patterns associated with $\mathrm{Pb}-\mathrm{Zn}$-Ba mineralization in the study area. The combination of these techniques towards discrimination of same alteration types ensures that the familiar subjectivity in interpretation associated with colour composite transforms is surmounted. Critical observation of the spectral plots of different samples of the same mineral considerably aided in either fine tuning existing Band Ratio composites or developing new ratios that assisted in enhancing mapping alteration zones. ASTER (Band 1+ Band 3)/ Band 2 gave a better result in mapping sulphide zones than the Band1/Band 4 (Cudahy, 2012). Generating composites from selected transform bands with relatively higher eigenvector bands (non-zero eigenvectors) especially at the absorption bands for target mineral groups has proven to yield effective discrimination of the mineral group of interest. This was found to be more applicable in situations where the non-zero eigenvector loadings of the absorption bands and the adjourning reflectance bands deviate significantly.

\section{Acknowledgements}

The ASTER level 1T data used for this study was provided by the land process Distributed Active Centre (LPDAAC), located at the US Geological Survey (USGS), Earth Resources Observation and Science (EROS) centre.

\section{Funding}

This work was supported by the Tertiary Education Trust Fund (TETFund) under Grant IBR/2017/80PS.

\section{References}

Abubakar, A. J., Hashim, M., \& Pour, A. B. (2018). Identification of hydrothermal alteration minerals associated with geothermal system using ASTER and Hyperion satellite data: a case study from Yankari Park, NE Nigeria. Geocarto International, 34, 597-624. https://doi.org/10.1080/10106049.2017.1421716

Ajakaiye, D. E. (1981). Geophysical investigation in the Benue-Trough. A review. Earth Evolution. Arbitrary shape. In parks, G.A Editor. Computers in the Minerals industries, Part 1: Stanford University Publication of Geological sciences, 9, 464-480.

Akande, S. O., \& Mucke, A. (1993). Co-existing copper sulphides and sulphosalts in the Abakaliki Pb-Zn deposit, Lower Benue Trough and their genetic implications. Journal of Mineralogy and Petrology, 47, 183-192. https://doi.org/10.1007/BF01161566

Akande, S. O., Horn, E. E., \& Reutel, C. (1988). Mineralogy, fluid inclusion and genesis of the Arufu and Akwana $\mathrm{Pb}-\mathrm{Zn}-\mathrm{F}$ mineralization, middle Benue Trough, Nigeria. Journal of African Earth Sciences, 7, 167-180. https://doi.org/10.1016/0899-5362(88)90063-2

Akande, S. O., Zentelli, M., \& Reynolds, P. H. (1989). Fluid inclusion and stable isotope studies of $\mathrm{Pb}-\mathrm{Zn}$-fluorite-barite mineralization in the lower and middle Benue Trough, Nigeria. Mineralium Deposita, 24, 183-191. https://doi.org/10.1007/BF00206441

Klimoski, R., \& Palmer, S. (1993). The ADA and the hiring process in organizations. Consulting Psychology Journal: Practice and Research, 45(2), 10-36. https://doi.org/10.1037/1061-4087.45.2.10

Benkhelil, J. (1982). Benue Trough and Benue Chain. Geological Magazine, 119, 155-168. https://doi.org/10.1017/S001675680002584X

Benkhelil, J. (1986). Structure et evolution geodynamique du basin intracontinental del la Benoue (Nigeria). These, Univ. Nice, 226p.

Benkhelil, J. (1987). Cretaceous deformation, magmatism and metamorphism in the Lower Benue Trough, Nigeria. Geological Journal, 22, 467-493. https://doi.org/10.1002/gj.3350220629

Benkhelil, J. (1989). The origin and evolution of the Cretaceous Benue Trough (Nigeria). Journal of African Earth Sciences, 8, 251 - 282. https://doi.org/10.1016/S0899-5362(89)80028-4

Boardman, J. W., \& Green, R. O. (2000). Exploring the Spectral Variability of the Earth as Measured by AVIRIS in 1999. Summaries of the Ninth Annual JPL Airborne Geosciences Workshop. Jet Propulsion Laboratory Special Publication 18, p. 10.

Chang, Q., Jing, L., \& Panahi, A. (2006). Principal component analysis with optimum order sample correlation coefficient for image enhancement. International Journal of Remote Sensing, 27, 3387-3401. https://doi.org/10.1080/01431160600606882

Cratchley, C. R., \& Jones, G. P. (1965). An interpretation of the geology and gravity anomalies of the Benue valley, 
Nigeria. Overseas Geol. Surv. Geophysical Paper No. 1.

Cudahy, T. J. (2012). Satellite ASTER Geoscience Product Notes for Australia. Australian ASTER Geoscience Product Notes, Version 1, August 07, 2012 - CSIR0 ePublish No. EP-30-07-12-44.

Cudahy, T. J., \& Ramanaidou, E. R. (1996). Measurement of the hematite-goethite ratio using field VNIR spectrometry in channel iron deposits, Western Australia. Australian Journal of Earth Sciences, 44(4), 411-421. https://doi.org/10.1080/08120099708728322

Cudahy, T. J., Jones, M., Thomas, M., Laukamp, C., Caccetta, M., Hewson, R. D., Rodger, A. D, \& Verrall, M. (2008). Next Generation Mineral Mapping: Queensland Airborne HyMap and Satellite ASTER Surveys 2006-2008. CSIRO report $\mathrm{P} 2007 / 364,153$ pages.

Dickson, B. L., \& Scott, K. M. (1997). Interpretation of aerial gamma ray surveys; adding the geochemical factors. AGSO Journal of Australian Geology and Geophysics, 17, 187-200.

Elsaid, M., Aboelkhair, H., Dardier, A., Elsayed, H., \& Minoru, U. (2014). Processing of multispectral ASTER data for mapping of alteration minerals zones: As an aid for uranium exploration in Elmissikat-Eleridiya. The Open Geology Journal, 8, 69-83. https://doi.org/10.2174/1874262901408010069

Etim, O. N., Louis, P., \& Maurin, J. C. (1988). Interpretation of electrical soundings on the Abakaliki Lead-Zinc and barite prospects, S.E. Nigeria: Geological and genetic implications. Journal of African Earth Sciences, 7, 743-747. https://doi.org/10.1016/0899-5362(88)90014-0

Ezepue, M. C. (1984). The geologic setting of lead-zinc deposits at Ishiagu, Southeastern Nigeria. Journal of African Earth Sciences, 2, 97-101. https://doi.org/10.1016/S0731-7247(84)80003-8

Farrington, J. L. (1952). A preliminary description of the Nigerian lead-zinc field. Economic Geology, 47, 583-608. https://doi.org/10.2113/gsecongeo.47.6.583

Ferrier, G., \& Wadge, G. (1996). Application of imaging spectrometry data to mapping alteration zones associated with gold mineralization in southern Spain. International Journal of Remote Sensing, 17, 331-350. https://doi.org/10.1080/01431169608949009

Ferrier, G., White, K., Griffiths, G., Bryant, R., \& Stefouli, M. (2002). The mapping of hydrothermal alteration zones on the island of Lesvos, Greece, using an integrated remote sensing data set. International Journal of Remote Sensing, 23, 341-356. https://doi.org/10.1080/01431160010003857

Green, A. A, Bermann, M., Switzer, P., \& Craig, M. D. (1988). A transformation for ordering multispectral data in terms of image quality with implications for noise removal. IEEE Transactions on Geoscience and Remote Sensing, 26, 65-74. https://doi.org/10.1109/36.3001

Gupta, R. P. (2018). Remote sensing geology. Springer Verlag GmbH Germany. 428pp. https://doi.org/10.1007/978-3-662-55876-8

Gupta, R. P., Tiwari, R. K., Saini, V., \& Srivastava, N. (2013). A simplified approach for interpreting principal component images. Advances in Remote Sensing, 2, 111-119. https://doi.org/10.4236/ars.2013.22015

Haest, M., Cudahy, T., Laukamp, C., \& Gregory, S. (2012). Quantitative mineralogy from visible to shortwave infrared spectroscopic data: Validation of mineral abundance and composition products of the Rocklea Dome Channel iron deposit in Western Australia. Economic Geology, 107, 209-228. https://doi.org/10.2113/econgeo.107.2.209

Haralick, R. M., \& Fu, K. (1983). Pattern recognition and classification. In: Colwell R.N (ed) Manual of remote sensing. American Society of Photogrammetry and Remote Sensing, Falls Church, VA, pp 793-805.

Hewson, R. D., Cudahy, T. J., Mizuhiko, S., Ueda, K., \& Mauger, A. J. (2005). Seamless geological map generation using ASTER in the Broken Hill-Curnamona province of Australia. Remote Sensing of Environment, 99, 159-172. https://doi.org/10.1016/j.rse.2005.04.025

Hosseinjani, M., \& Tangestani, M. H. (2011). Mapping alteration minerals using sub-pixel unmixing of ASTER data in the Sarduiyeh area, SE Kerman, Iran. International Journal of Digital Earth, 4, 487-504. https://doi.org/10.1080/17538947.2010.550937

Kalinowski, A., \& Oliver, S. (2004). ASTER Mineral Index Processing Manual. Remote Sensing Applications, Geoscience Australia.

Loughlin, W. P. (1991). Principal components analysis for alteration mapping. Photogrammetric Engineering and Remote Sensing, 57, 1163-1169.

Mackay, R. A. (1946). A comparative study of two lead-zinc occurrences in Plateau and Ogoja Provinces. Annual 
Report of the Geological Survey of Nigeria. Bulletin No. 19. 84pp.

Maurin, J. C., \& Benkhelil, J. (1990). Model of Pb/Zn mineralization genesis in the Cretaceous Benue Trough (Nigeria): Structural, geophysical and geochemical constraints. Journal of African Earth Sciences, 11, 345-349. https://doi.org/10.1016/0899-5362(90)90013-5

Mbah, V. O., Onwuemesi, A. G., \& Aniwetalu, E. U. (2015). Exploration of lead-zinc (Pb-Zn) mineralization using very low frequency electromagnetic (VLF-EM) in Ishiagu, Ebonyi State. Journal of Geology and Geosciences, 4, 214-221. https://doi.org/10.4172/2329-6755.1000214

Moghtaderi, A., Moore, F., \& Mohammadzadeh, A. (2007). The application of advanced space-borne thermal emission and reflection (ASTER) radiometer data in the detection of alteration in the Chadormalu paleocrater, Bafq region, Central Iran. Journal of Asian Earth Sciences, 30, 238-252. https://doi.org/10.1016/j.jseaes.2006.09.004

Oha, I. A., Onuoha, K. M., \& Dada, S. S. (2017). Contrasting styles of lead-zinc-barium mineralization in the Lower Benue Trough, Southeastern Nigeria. Earth Science Research Journal, 21, 7-14. https://doi.org/10.15446/esrj.v21n1.39703

Ojoh, K. A. (1992). The Southern part of the Benue Trough (Nigeria) Cretaceous Stratigraphy, Basin Analysis, paleo-oceanography and Geodynamic Evolution in the Equatorial Domain of the South Atlantic. Nigerian Association of Petroleum Explorationists (NAPE). Bull, 7(2), 131-152.

Olade, M. A. (1976). On the genesis of the lead-zinc deposits in Nigerians Benue rift (aulacogen) a re-interpretation. Nigerian Journal of Mining Geology, 13, 20-27.

Olade, M. A., \& Morton, R. D. (1985). Origin of lead-zinc mineralization in the southern Benue Trough, Nigeria, fluid inclusion and trace element studies. Mineralium Deposita, 20, 76-80. https://doi.org/10.1007/BF00204313

Orajaka, S. (1965). Geology of Enyigba, Ameri and Ameka lead-zinc mines. Journal of Geology, 3, 49-51.

Petters, S. W., \& Ekweozor, C. M. (1982). Petroleum geology of the Benue Trough and southeastern Chad Basin, Nigeria. Am. Assoc. Geol. Bull, 68(8), $1141-1149$.

Pour, A. B., \& Hashim, M. (2011). Identification of hydrothermal alteration minerals for exploring of copper deposit using ASTER data, SE Iran. Journal of Asian Earth Sciences, 42, 1309-1323. https://doi.org/10.1016/j.jseaes.2011.07.017

Reyment, R. A. (1965). Aspects of the Geology of Nigeria. Ibadan University Press. 145 pp.

Rowan, L. C., \& Mars, J. C. (2003). Lithologic mapping in the Mountain Pass, California area using Advanced Spaceborne Thermal Emission and Reflection Radiometer (ASTER) data. Remote Sensing of Environment, 84, 350-366. https://doi.org/10.1016/S0034-4257(02)00127-X

Rowan, L. C., Mars, J. C., \& Simpson, C. J. (2005). Lithologic mapping of the Mordor, NT, Australia ultramafic complex by using the Advanced Spaceborne Thermal Emission and Reflection Radiometer (ASTER). Remote Sensing of Environment, 99, 105-126. https://doi.org/10.1016/j.rse.2004.11.021

Ruiz-Armenta, J. R., \& Prol-Ledesma, R. M. (1998). Techniques for enhancing the spectral response of hydrothermal alteration minerals in thematic mapper images of central Mexico. International Journal of Remote Sensing, 19, 1981-2000. https://doi.org/10.1080/014311698215108

Sekandari, M., Masoumi, I., Pour, A. B., Muslim, A. M., Hossain, M. S., \& Misra, A. (2020). ASTER and WorldView-3 satellite data for mapping lithology and alteration minerals associated with $\mathrm{Pb}-\mathrm{Zn}$ mineralization. Geocarto International, online first. 1-23. https://doi.org/10.1080/10106049.2020.1790676

Singh, A., \& Harrison, A. (1985). Standardized principal components. International Journal of Remote Sensing, 6, 883-896. https://doi.org/10.1080/01431168508948511

Tayebi, M. H., Tangestani, H. M., \& Roosta, H. (2013). Mapping salt diapirs and salt diapir-affected areas using MLP neural network model and ASTER data. International Journal of Digital Earth, 6, $143-157$. https://doi.org/10.1080/17538947.2011.606336

Umeji, O. P. (2007). Late Albian to Campanian palynostratigraphy of Southeastern Nigerian sedimentary Basins: Unpublished Ph.D Thesis, Department of Geology, University of Nigeria, Nsukka, 280p. 


\section{Copyrights}

Copyright for this article is retained by the author(s), with first publication rights granted to the journal.

This is an open-access article distributed under the terms and conditions of the Creative Commons Attribution license (http://creativecommons.org/licenses/by/4.0/). 